\title{
CAMA
}

Centre for Applied Macroeconomic Analysis

\section{The effect of fuel prices on traffic flows: Evidence from New South Wales}

\section{CAMA Working Paper 86/2020 October 2020}

\section{Tong Zhang}

Australian National University

\section{Paul J. Burke}

Crawford School of Public Policy, ANU

Centre for Applied Macroeconomic Analysis, ANU

\begin{abstract}
Understanding how traffic flows respond to fuel price changes is useful for traffic management. This study uses a dataset of 11.9 million hourly observations from 118 traffic count stations over 2010-2017 to investigate the relationship between the gasoline price and traffic flows in the state of New South Wales, Australia. The findings suggest that higher gasoline prices reduce traffic flows, with an average effect size of -0.04 in the hourly estimates. The elasticity is particularly pronounced during off-peak periods, both on weekdays $(-0.10)$ and weekends $(-0.07)$. In contrast, a positive effect of gasoline prices on traffic flows is observed for peak periods on weekdays (0.06). Evidence is also obtained that afternoon peak-hour speeds are faster when gasoline prices are higher, consistent with a lowering of traffic density. The research also finds a negative price elasticity of gasoline demand and that people are more likely to use public transport when gasoline prices are higher. The findings suggest that fuel excise plays a role in both reducing overall road dependence and alleviating the severity of some peak-hour traffic jams.
\end{abstract}




\section{Keywords}

gasoline price, traffic flow, speed, road transport, public transport

\section{JEL Classification}

R41, Q41, Q43

\section{Address for correspondence:}

(E) cama.admin@anu.edu.au

\section{ISSN 2206-0332}

The Centre for Applied Macroeconomic Analysis in the Crawford School of Public Policy has been established to build strong links between professional macroeconomists. It provides a forum for quality macroeconomic research and discussion of policy issues between academia, government and the private sector.

The Crawford School of Public Policy is the Australian National University's public policy school, serving and influencing Australia, Asia and the Pacific through advanced policy research, graduate and executive education, and policy impact. 


\title{
The effect of fuel prices on traffic flows: Evidence from New South Wales
}

\author{
Tong Zhang, Paul J. Burke* \\ Australian National University, ACT 2601, Australia \\ * Corresponding author: paul.j.burke@anu.edu.au, +61 261256566
}

\begin{abstract}
Understanding how traffic flows respond to fuel price changes is useful for traffic management. This study uses a dataset of 11.9 million hourly observations from 118 traffic count stations over 2010-2017 to investigate the relationship between the gasoline price and traffic flows in the state of New South Wales, Australia. The findings suggest that higher gasoline prices reduce traffic flows, with an average effect size of -0.04 in the hourly estimates. The elasticity is particularly pronounced during off-peak periods, both on weekdays $(-0.10)$ and weekends $(-0.07)$. In contrast, a positive effect of gasoline prices on traffic flows is observed for peak periods on weekdays (0.06). Evidence is also obtained that afternoon peak-hour speeds are faster when gasoline prices are higher, consistent with a lowering of traffic density. The research also finds a negative price elasticity of gasoline demand and that people are more likely to use public transport when gasoline prices are higher. The findings suggest that fuel excise plays a role in both reducing overall road dependence and alleviating the severity of some peak-hour traffic jams.
\end{abstract}

Keywords: gasoline price; traffic flow; speed; road transport; public transport

JEL codes: R41, Q41, Q43

Acknowledgements: The authors are grateful for comments from two anonymous reviewers and presentations at the Australian National University and the Australasian Agricultural and Resource Economics Society (AARES) Conference 2019. The work was supported by the China Scholarship Council (CSC201706980025) and Australian Research Council (DE160100750). 


\section{Introduction}

Traffic congestion is estimated to cost more than A $\$ 5$ billion per annum across metropolitan Sydney, a figure that has been predicted to reach around A $\$ 8$ billion by 2021 (NSW Government 2019). There are many factors that are likely to affect road traffic demand, including demographic, geographic, and economic variables. Among these, prices are likely to be key factors that drivers take into account when considering how, where, and when to travel (Litman 2019). Transport prices include fuel prices, road tolls, parking fees, and public transport charges. Fuel prices are particularly relevant given the size of fuel costs in the cost of driving. Understanding motorist responses to fuel price changes is useful for plans to manage growing road traffic flows and for pursuing objectives such as easing traffic jams, improving road safety, and reducing atmospheric pollution.

Fuel prices are thought to affect road traffic demand primarily via the following mechanisms:

1. When fuel prices are high, drivers may reduce trip frequency and distance. They could do this by working at home or by substituting to closer locations (Austin 2008).

2. Higher fuel prices could cause drivers to change their commuting modes. For example, they may switch from personal cars to carpooling or public transport (Currie and Phung 2008; Fullerton and Walke 2013; Rohani and Pahazri 2018).

3 . In the longer run, people may adjust their home and work locations in response to a higher fuel price (Graham and Glaister 2002; Chi et al. 2013).

This paper focuses on the effect of gasoline prices on observed traffic flows. Traffic flows are useful to study as a higher flow means that more vehicles are enjoying the benefit of flowing past a specific point during a given time window. Traffic flow is expected to be monotonically related to traffic demand in conditions that are not hypercongested. In hypercongested conditions, a reduction in traffic demand would be expected to lead to boosted traffic flow due to the alleviation of traffic jams.

New South Wales (NSW), Australia's most populous state, was chosen as a case study because it has an extensive network of traffic count stations for which hourly data on vehicle flows are available over a relatively long period. The study uses what is thought to be the largest dataset to date on road traffic vehicle flows - around 11.9 million observations. ${ }^{1}$ These are hourly observations from 118 traffic flow count stations over the period January 2010-December 2017.

The analysis utilizes the richness of the dataset to explore potential heterogeneity in effects. Gasoline price elasticities of traffic flow are estimated separately for peak and off-peak periods, and heterogeneity analysis is carried out for Greater Sydney versus outside Greater Sydney, the Sydney central business district (CBD) versus elsewhere, toll roads versus toll-free roads, and highways versus other roads. Estimates of the gasoline price elasticity of peak-hour speeds, the gasoline own-price elasticity of demand, and the gasoline price elasticity of public transport ridership are presented, and lagged effects of gasoline prices on traffic flows are explored. To address potential endogeneity issues, the log world crude oil price is used to instrument the log local gasoline price in some estimates.

\footnotetext{
${ }^{1}$ Although the raw dataset used by Bento et al. (2013) has 114 million observations, they summed hourly traffic flows to the weekly level, arriving at an estimation sample of around 700,000 observations.
} 
The results indicate that higher gasoline prices on average reduce hourly traffic flows, with an effect size that is highly inelastic. The gasoline price elasticities of traffic flows during off-peak periods on both weekdays and weekends are negative. A positive elasticity is obtained for weekday peak periods, a finding that suggests that higher gasoline prices help to alleviate hypercongestion at these times. It is also found that higher gasoline prices lead to an increase in travel speeds in afternoon peak periods, consistent with a reduction in the density of vehicles on the road. The medium-run impact of higher gasoline prices on vehicle flows is found to be similar to the short-run impact. The proportional effect of gasoline price changes on the quantity of gasoline demanded is larger than the effect on traffic flows, and a positive relationship is observed between gasoline prices and the use of public transport.

There are numerous studies that have investigated road-sector responses to gasoline prices. Most have found that people choose to reduce driving or switch to more fuel-efficient vehicles to save fuel when fuel prices increase (Dahl 1979; Dahl and Sterner 1991; Goodwin et al. 2004; Gillingham 2011; Li et al. 2012; Gillingham and Munk-Nielsen 2019). A negative relationship between fuel prices and road fatalities has been found for both Australia and elsewhere (Grabowski and Morrisey 2004; Wilson et al. 2009; Chi et al. 2010; Burke 2014; Burke and Nishitateno 2015; Burke and Teame 2018; Best and Burke 2019).

From a policy point of view, fuel excise can be seen as an alternative to distance-based road pricing, although one that is insensitive to the location and time of driving and is only relevant for vehicles with internal combustion engines. Congestion pricing is a theoretically superior approach for addressing congestion externalities provided that it can be efficiently implemented. While various forms of road-use pricing have been discussed in Australia

(Productivity Commission 2006), little progress has been made towards adoption. The traffic flow and speed results in this paper provide information that helps to understand the effect of gasoline prices on the underlying level of congestion.

The remainder of the paper is structured as follows. Section 2 briefly describes traffic flow theory, which underpins the analysis. Section 3 describes the data. Section 4 describes the empirical model. Section 5 reports the empirical results. Section 6 investigates the impact of fuel price changes on fuel demand and public transport. Section 7 relates the results to prior studies. Section 8 concludes.

\section{Traffic flow theory}

The fundamental equation for the relationship between the three characteristics of traffic - flow, density, and speed - is:

$q=k v$

where $q$ is flow, defined as the rate at which vehicles pass a point on a road, measured in vehicles per hour; density $k$ is the number of vehicles occupying a given length of roadway, measured in vehicles per kilometer; and $v$ is the space-mean speed, measured in kilometers per hour on average for each vehicle.

Figure 1 sketches these relationships in the form of the fundamental diagram of traffic flow. The traffic state can be divided into two primary regimes. If density is below the road's capacity 
$k_{c}$, it is called the "congested state". When the density is near zero, people can drive at a maximum speed of $v_{f}$ (free speed) determined by the performance of vehicles and the conditions and speed limit of the roadway, without stress from other vehicles. If density is near zero, the flow is also near zero because there are few vehicles on the road. As the density increases, the flow also increases since more vehicles are using the road, and the average speed tends to decline somewhat due to the presence of other vehicles. This continues until $k_{c}$.

When $k_{c}$ is reached, this is called the "hypercongested state". Average speed starts to reduce sharply because of the large number of vehicles on the road. The flow of vehicles also starts to decline. The maximum density is called $k_{j}$ (“jam density”). At $k_{j}$, average speed slows to zero. The flow approaches zero as well because vehicles cannot move.

Figure 1 Fundamental diagram of traffic flow

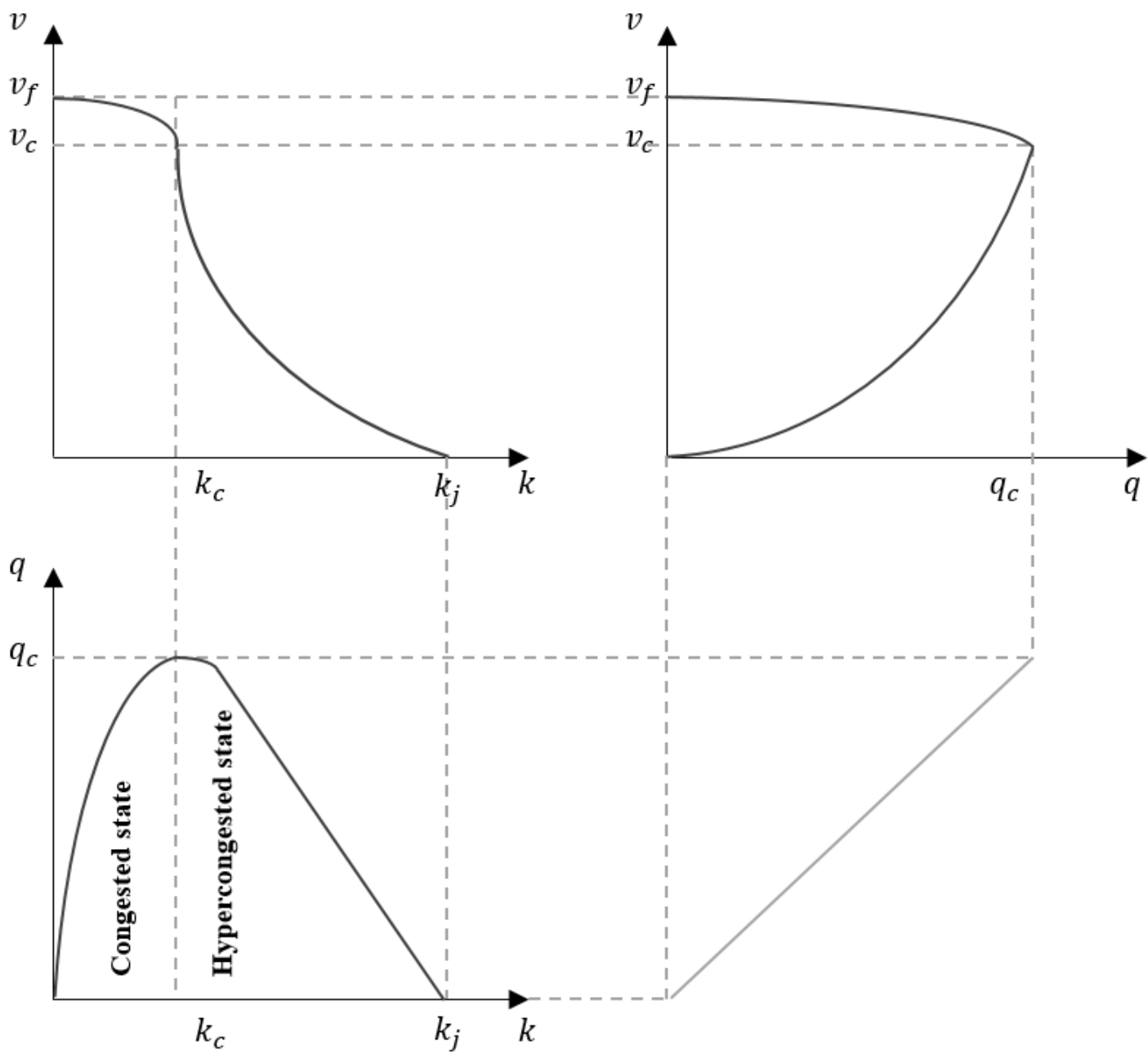

Source: Immers and Logghe (2003)

The focus of the econometric estimations in this study is traffic flows rather than densities. Flows represent the number of people benefiting from the transport service in a time window (i.e. number of people flowing past a count station in an hour), which is a valuable measure. It is also the measure that is comparable to the public transport flow data that are utilized later in the paper, such as data on the number of people using the bus system in a month. Prior studies 
also tend to focus on flow data (e.g. Burke et al. 2017). Density data (vehicles per kilometer) are not available for the roads in the study.

From a theoretical point of view, a higher gasoline price should be expected to reduce density $k$ due to fewer people heading out to drive. This will lead to either a reduction or an increase in flow $q$ depending on whether the traffic would otherwise have been in a congested or a hypercongested state. If the road would otherwise have been in a congested state, as the density decreases the flow will decrease. If the road would otherwise have been in a hypercongested state, decreases in density should be expected to lead to an increase in both the average speed and the flow of vehicles.

\section{Data and initial testing}

\subsection{Data}

Traffic flow data are from the NSW Roads and Maritime Services (2019a), which collects traffic information at roadside traffic count stations for both directions of selected roads. ${ }^{2}$ These traffic count stations only count the number of vehicles that pass, and not their type. Another type of station is a classifier station, which differentiates between light and heavy vehicles. Data are only available for 18 classifier stations, so heterogeneity analysis for light and heavy vehicles is not pursued. The data cover all motor vehicles, and do not cover other vehicles such as bicycles. Raw traffic flow data for each traffic count station, by traffic flow direction, are available on an hourly basis from 2006 onwards. Where possible, the regressions use data for each direction of a road (as separate stations). Efforts have been made by NSW Roads and Maritime Services to ensure high data quality.

This study uses a panel of traffic flows at 118 traffic count stations over the period January 2010-December 2017. The sample starts in 2010 to avoid more frequently missing data in earlier years. There are some remaining instances of missing or zero values, for example when a monitor's battery or power source is compromised. This issue is handled as follows. If a day includes a missing/zero hour, that day was deleted from the daily dataset, that week from the weekly dataset, and that month from the monthly dataset. If data are not available for a station for a whole year between 2010 and 2017, that station is excluded from the dataset.

Figure 2 shows the locations of the 118 traffic count stations. Most are clustered in and around Sydney and Newcastle, the two largest cities in NSW. Most of the others are near or on the way to a city. For example, station code 94046 is on the Federal Highway between Canberra and Sydney. Station 1003 is in the Sydney Harbour Tunnel, one of the busiest roads in NSW (used by over 43 million vehicles each year; NSW Roads and Maritime Services (2019a)). The sample includes 2 toll roads and 116 toll-free roads. The roads can also be classified into highways (29) and non-highways (89).

\footnotetext{
${ }^{2}$ NSW Roads and Maritime Services maintains approximately 600 permanent count and classifier stations across NSW, collecting data for every hour of the year. It also maintains some temporary stations.
} 
Figure 2 Traffic count stations in the sample

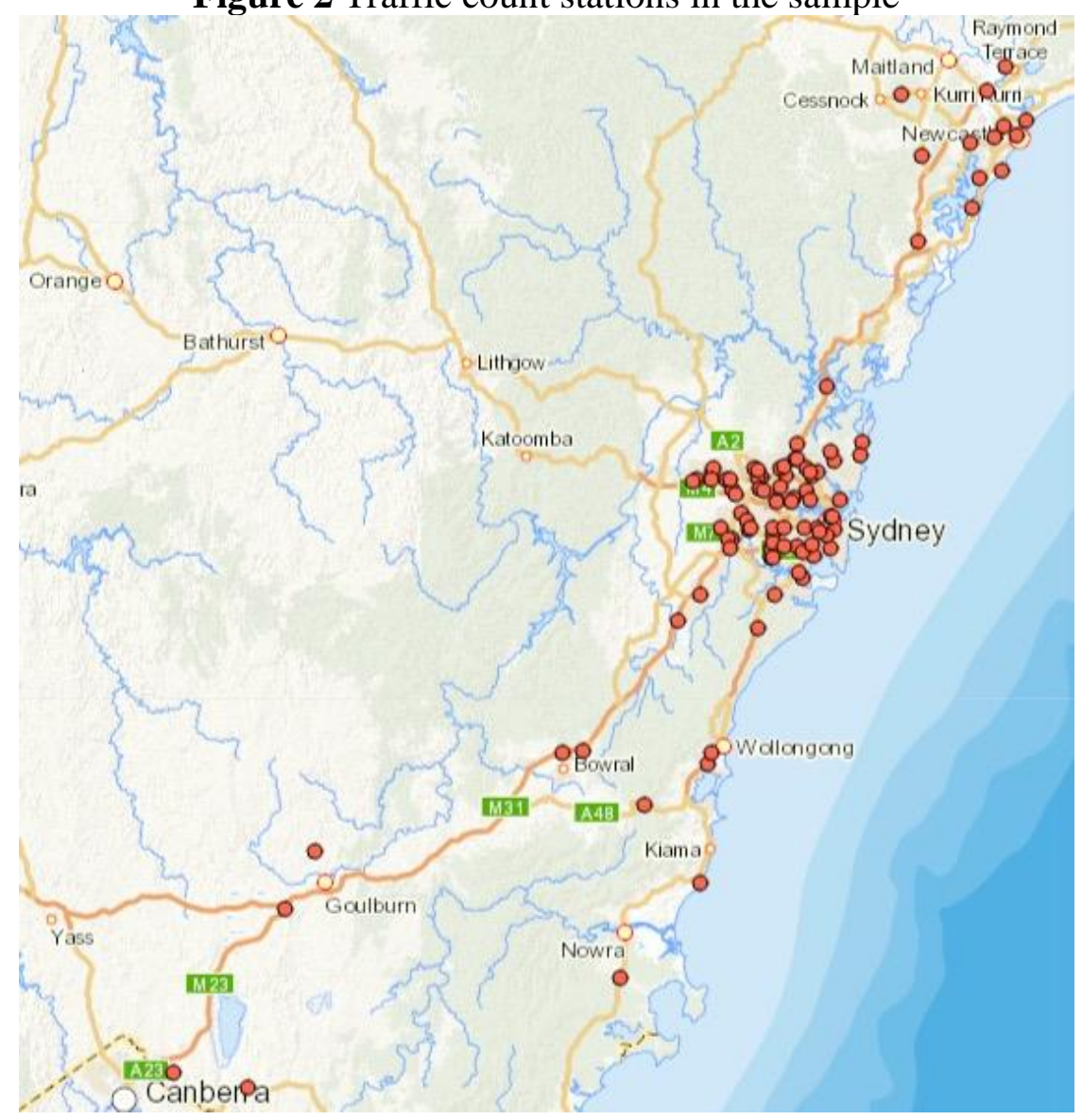

Source: NSW Roads and Maritime Services (2019a).

Notes: Some stations overlap on this map. Only stations in the sample are shown.

The daily fuel price is measured using Sydney's average terminal gate price (TGP) for gasoline (unleaded petrol). A TGP is the price at which an oil terminal sells tankerloads of fuel to wholesale customers (Australian Institute of Petroleum 2002). The TGP is inclusive of fuel excise and the $10 \%$ goods and services tax (GST), but excludes margins for subsequent freight costs, branding, service-station wages, and profits (BP Australia 2019). ${ }^{3}$ Table 1 presents summary statistics for the variables used in the main regressions. The raw hourly traffic flow dataset consists of about 11.9 million observations. Variable definitions and data sources are shown in the Appendix.

\footnotetext{
${ }^{3}$ The excise tax on unleaded petrol in Australia was A\$0.416 per liter as of February 2019.
} 
Table 1 Summary statistics

\begin{tabular}{|c|c|c|c|c|c|c|c|c|}
\hline & Observations & Mean & Std. dev. & Min & Max & Skewness & Kurtosis & $\begin{array}{l}\text { Coefficient of } \\
\text { variation }\end{array}$ \\
\hline Flow (hourly) & $11,942,105$ & 771 & 753 & 0 & 22,690 & 1.25 & 4.52 & 0.98 \\
\hline Flow (daily) & 490,362 & 18,486 & 11,571 & 1 & 146,723 & 0.52 & 2.94 & 0.63 \\
\hline Flow (weekly) & 58,692 & 131,972 & 78,631 & 1,827 & 493,153 & 0.45 & 2.83 & 0.60 \\
\hline Flow (monthly) & 5,922 & 591,481 & 344,372 & 8,627 & $1,865,407$ & 0.41 & 2.81 & 0.58 \\
\hline Gasoline price (real) & 2,922 & 135.26 & 17.05 & 98.54 & 162.69 & -0.43 & 1.8 & 0.13 \\
\hline S\&P/ASX 200 price & 2,922 & 5,061 & 540.55 & 3,864 & 6,088 & -0.18 & 1.96 & 0.11 \\
\hline Rainfall (mm) & 2,892 & 3.74 & 11.19 & 0 & 135.8 & 5.53 & 43.01 & 2.99 \\
\hline Maximum temperature $\left({ }^{\circ} \mathrm{C}\right)$ & 2,922 & 23.2 & 4.49 & 11.7 & 45.8 & 0.47 & 3.53 & 0.20 \\
\hline Unemployment rate $(\%)$ & 96 & 0.053 & 0.004 & 0.045 & 0.062 & 0.002 & 0.022 & 0.08 \\
\hline World crude oil price (real) & 2,922 & 56.37 & 13.77 & 23.92 & 83.70 & -0.28 & 1.81 & 0.24 \\
\hline Gasoline pump price (real) & 96 & 146.04 & 15.75 & 111.93 & 169.40 & -0.54 & 2.06 & 0.11 \\
\hline Average speed (morning peak; $\mathrm{km} / \mathrm{h}$ ) & 1,070 & 41.03 & 16.69 & 132 & 2 & 1.37 & 5.56 & 0.41 \\
\hline Average speed (afternoon peak; $\mathrm{km} / \mathrm{h}$ ) & 1,070 & 40.56 & 17.08 & 103 & 11 & 1.32 & 4.59 & 0.42 \\
\hline Consumer confidence index & 90 & 114.84 & 4.42 & 102.40 & 127.50 & 0.37 & 3.78 & 0.04 \\
\hline Sales of gasoline (megaliters) & 90 & 433.13 & 26.48 & 433.13 & 578.41 & 0.56 & 3.54 & 0.06 \\
\hline Opal card utilization (all modes) & 30 & $57,646,968$ & $4,610,456$ & $48,453,400$ & $65,733,832$ & -0.03 & 2.10 & 0.08 \\
\hline Opal card utilization (train) & 30 & $31,831,688$ & $2,553,120$ & $26,735,422$ & $36,322,564$ & -0.10 & 2.01 & 0.08 \\
\hline Opal card utilization (bus) & 30 & $23,740,110$ & $2,153,247$ & $19,550,896$ & $27,352,356$ & 0.01 & 2.08 & 0.09 \\
\hline Opal card utilization (light rail) & 30 & 786,722 & 140,947 & 193,720 & 879,306 & -3.12 & 12.70 & 0.18 \\
\hline Opal card utilization (ferry) & 30 & $1,288,448$ & 169,666 & $1,095,055$ & $1,738,083$ & 1.06 & 3.40 & 0.13 \\
\hline
\end{tabular}

Opal card utilization (ferry)

$1,288,448 \quad 169,666$

$1,095,055 \quad 1,738,083$

1.06

3.40

0.13

作

log. Gasoline price, S\&P/ASX 200 price, rainfall, temperature, and the world crude oil price are measured on a daily basis. Because the gasoline price, world crude oil price, and S\&P/ASX 200 price data contain missing values on weekends and some specific days, the price on Friday is used for weekends and a

linear interpolation method is used to fill any other gaps. The unemployment rate, gasoline pump price, average speed, consumer confidence index, sales of gasoline, and Opal card utilization are measured monthly. 
To gain an understanding of the data, Figure 3 plots the average daily vehicle flow for one major road, the Sydney Harbour Tunnel, against the real gasoline price for 2010-2017. Seasonality can be seen in the vehicle flow data. For example, the number of users tends to be lower in January, the time of summer holidays. The traffic flow data appear to be relatively inelastic in their response to fuel prices, although this will be more readily discernible using econometric estimations.

Figure 3 Average daily traffic flow for the Sydney Harbour Tunnel versus the real gasoline price, 2010-2017

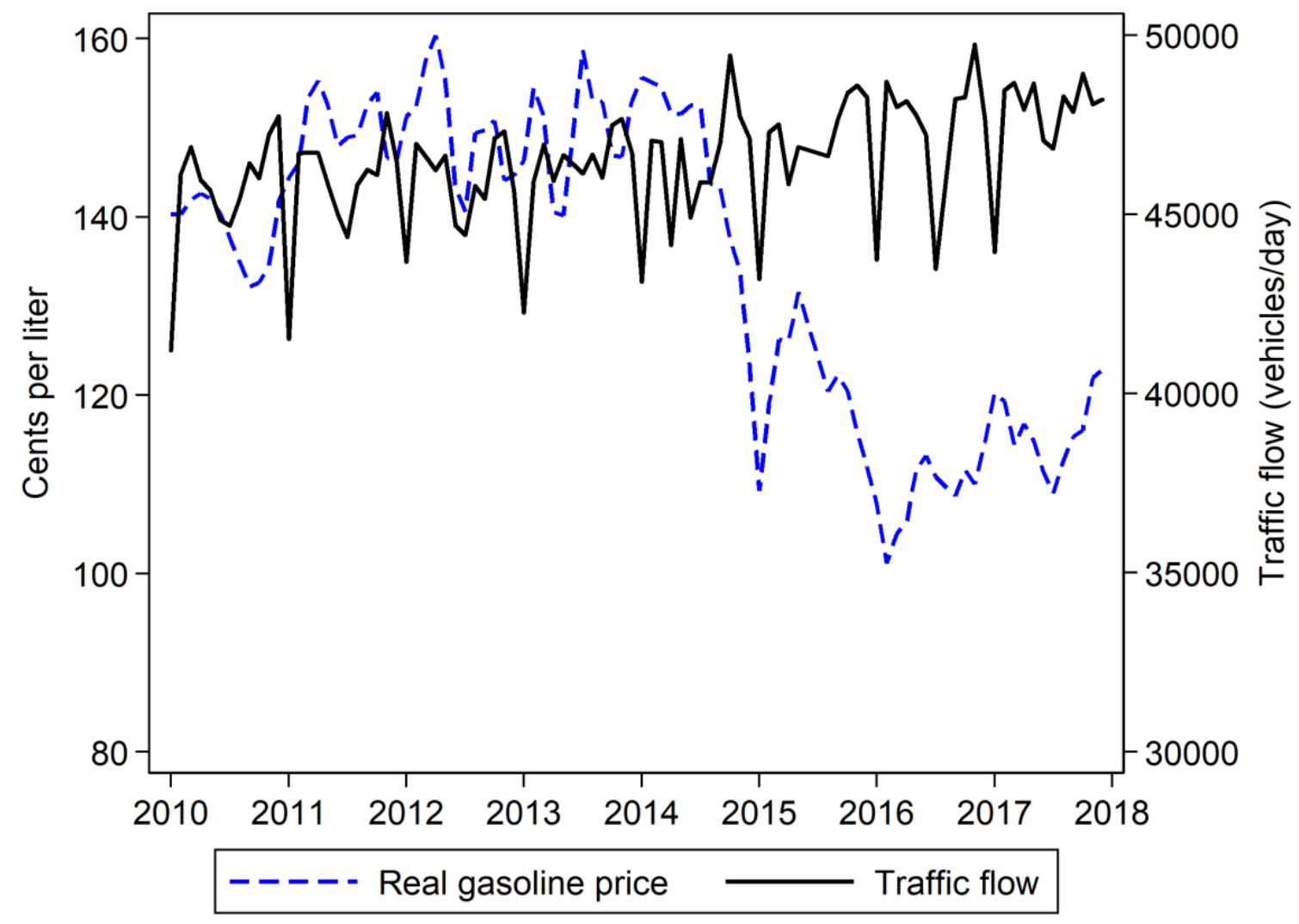

Source: NSW Roads and Maritime Services (2019a) and Australian Institute of Petroleum (2019). Notes: Gasoline price data are monthly. Traffic flow is the monthly average of daily flows on the northbound lanes of the Sydney Harbour Tunnel.

\subsection{Unit root testing}

Before estimating the model, stationary tests were conducted. ${ }^{4}$ The key independent variables (log real gasoline price, log S\&P/ASX 200 price, rainfall, maximum temperature, unemployment rate) have a single time series because only state-level data are utilized. Augmented Dickey and Fuller (ADF) (1979) unit-root tests were conducted for these variables, with lag lengths chosen based on the Bayesian information criterion. Trend terms were included for variables that appear to display a trend. The results of unit root tests for independent variables are shown in Table 2.

\footnotetext{
${ }^{4}$ The software used for all regressions is Stata.
} 
Table 2 Augmented Dickey-Fuller unit root test results for key independent variables

\begin{tabular}{llllll}
\hline Variables & Observations & Lags & Trend & $\begin{array}{l}\text { Test } \\
\text { statistic }\end{array}$ & $p$-value \\
\hline Ln real gasoline price (daily) & 2,916 & 5 & Yes & -2.86 & 0.18 \\
Ln S\&P/ASX 200 price & 2,920 & 1 & Yes & -3.21 & 0.08 \\
Rainfall (mm) & 2,837 & 1 & No & -31.72 & 0.00 \\
Maximum temperature $\left({ }^{\circ} \mathrm{C}\right)$ & 2,915 & 6 & No & -7.28 & 0.00 \\
Unemployment rate (Jan 2010-Dec 2017) & 93 & 2 & Yes & -1.54 & 0.81 \\
Unemployment rate (Jan 1998-Dec 2017) & 237 & 2 & Yes & -3.23 & 0.08 \\
\hline
\end{tabular}

Notes: Lag length are chosen by Bayesian information criterion. Whether the test includes a trend term depends on visual inspection of each variable. Data for the log S\&P/ASX 200 price, rainfall, and temperature are daily. Data for the unemployment rate are monthly.

The null of a unit root can be rejected at the $1 \%$ significance level for rainfall and maximum temperature and the $8 \%$ level for the log S\&P/ASX 200 price. For the daily log real gasoline price, the null of a unit root cannot be rejected. Although the null of a unit root for the unemployment rate cannot be rejected for the sample period, it can be rejected at the $8 \%$ level when data for a longer time period are tested. Phillips and Perron (1988) tests were also carried out, with the results being quite similar.

The situation for the traffic flow data is more complicated given their panel nature. A Fishertype test (Choi 2001) was carried out for log hourly traffic flow. The null that all panels each contain a unit root was rejected at the $1 \%$ significance level. On the basis of the unit root tests, and for parsimony, estimations are carried out in levels rather than first differences.

\subsection{Cross-sectional dependence}

Some stations are on the same road. For example, nine are on the Pacific Highway and nine on the Princes Highway. For this and other reasons there are concerns over cross-sectional dependence. A Pesaran (2004) test for cross-sectional dependence was conducted for the daily estimations. The result suggests that the null of cross-sectional independence can indeed be rejected at the $1 \%$ significance level. Results using Driscoll and Kraay (1998) standard errors, which are heteroscedasticity-consistent and robust to general forms of cross-sectional and temporal dependence (Hoechle 2007), are similar.

\section{Model}

The relationship between hourly count station traffic flows and the daily gasoline price is investigated using the following model:

$\ln T F_{i, t}=\beta_{0}+\beta_{1} \ln P_{i, t}+\beta_{2} T_{t}+\beta_{2} H_{h: d}+\beta_{3} D_{d: w}+\beta_{4} M_{m: y}+X^{\prime}{ }_{t} \boldsymbol{\varphi}+S_{i}+\varepsilon_{i, d}$

where $T F_{i, t}$ is the traffic volume for station $i$ in hour $t, P$ is the daily real TGP, $T$ is a time trend, $H$ is hour-of-day dummy variables, $D$ is day-of-week dummy variables, $M$ is month-of-year dummy variables, $\boldsymbol{X}$ is a vector of additional control variables consisting of a public holiday binary variable, a school holiday binary variable, a binary variable for double demerit periods 
(times when penalties for breaking traffic laws are higher) ${ }^{5}$, a binary variable for new clearways, a binary variable for daylight saving doubled-up hours (which occur once per year), the log S\&P/ASX 200 price, rainfall, and the maximum temperature during the day. $S$ represents station fixed effects. $\varepsilon$ is an error term. Use the daily rather than the hourly gasoline price appears to be reasonable, as drivers do not purchase fuel on a high-frequency basis.

The reasons for including the above explanatory variables are as follows. The time trend is included to account for the effects of gradual changes such as population and income growth, vehicle improvements, and the like. The hour-of-day dummies and day-of-week dummies control for regular variation in traffic flows throughout the day and the week. Month-of-year dummies capture seasonal effects. The public holiday dummy and school holiday dummy are included to take the effects of these special events into account. The double demerit period dummy is included because drivers might exhibit different behaviour during periods of higher infringement penalties. The daylight saving doubled-up hour dummy is included because the end of daylight savings has two hours on the same day that both commence at $2 \mathrm{am}$. This inflates traffic flows for this "hour".

To reduce congestion, in December 2013 the NSW Government (2013) announced a Sydney Clearways Strategy that saw the introduction of new or extended clearways on major roads. A clearway is a part of road where drivers are not permitted to park or stop during a certain period. ${ }^{6}$ The new clearway dummy is included to reflect possible effects from this change. There are five stations in the sample on roads for which a changes to a clearway were introduced. Their road names and clearway operation times are shown in Table A1 in the Appendix. Changes include extensions to the hours of operation during peaks or the length of the clearway.

The S\&P/ASX 200 price is the stock market index of 200 major stocks listed on the Australian Securities Exchange. It is included to control for expectations about the economy. An advantage of this variable over gross domestic product, for example, is that it is available at high frequency. Rainfall is included because people may change their driving behaviour under adverse weather conditions due to concerns over issues such as visibility, safety, and travel speeds (Billot et al. 2009). Station fixed effects control for characteristics that do not change over time, such as road location.

The data allow for the exploration of potential effect heterogeneity by the hour of day. Daily, weekly, and monthly estimations are also presented. The hour-of-day dummies and the daylight saving doubled-up hour dummy are only included in the hourly estimations. The day-of-week dummies are excluded from the weekly and monthly estimations. The daily-average gasoline price, S\&P/ASX 200 price, rainfall, and temperature variables are included in all specifications. The public holiday dummy, school holiday dummy and double demerit period dummy are switched to measures of the number of public holidays (school holidays or double demerit days) in each week or month for the weekly/monthly estimations. The daylight saving doubled-up

\footnotetext{
${ }^{5}$ In 1997, a demerit point scheme was introduced in NSW to encourage safer driving. It allocates penalty points for a range of driving offences, including speeding, not wearing a seatbelt, riding without a motorcycle helmet, and illegal use of mobile phones.

${ }^{6}$ Taxis and buses are allowed to stop to pick up or drop off passengers.
} 
hour dummy is switched to an "end of daylight saving" dummy in the daily and weekly estimations. The monthly estimations also control for the unemployment rate so as to capture the impact of this variable on road transport demand.

A concern is that third factors such as the underlying demand for transport may affect both gasoline prices and traffic flows, thus introducing a potential endogeneity challenge. To address this issue, specifications are presented using the log real world crude oil price to instrument the log real gasoline price. The cost of imported crude oil is a significant contributor to the gasoline price (Australian Competition and Consumer Commission 2016) and is largely exogenous to Australian demand. The instrumental variable is assumed to affect the dependent variable only via the gasoline price and not other channels. Any effects on economic expectations are in part controlled for by the stock market price index variable. The approach of instrumenting the local gasoline price with the world crude oil price has been used in previous studies (Burke and Nishitateno 2013, 2015; Burke and Teame 2018; Best and Burke 2019).

The empirical results are extended along several dimensions. First, whether the gasoline price elasticity of vehicle flows depends on the time of day is investigated. Second, heterogeneity analysis based on different station groups is conducted. Third, a distributed lag model is estimated by including lags of the gasoline price variable of up to 120 days. This complements the main results using the static fixed effect estimator, which picks up fairly short-run effects (Torres-Reyan 2007). The study also estimates the gasoline price elasticity of average vehicle speeds, the gasoline own-price elasticity of demand, and the gasoline price elasticity of public transport ridership in NSW.

\section{Results}

\subsection{Initial results}

Table 3 presents estimates of Eq (2). All of the coefficients for the log real gasoline price are negative and all other than the monthly estimates are significantly different from zero. The estimate using the hourly data in column 1 is -0.04 , which is significantly different from zero at the $1 \%$ level. This implies that a $1 \%$ increase in gasoline prices on average leads to a $0.04 \%$ decrease in hourly traffic flows, holding other variables constant. Columns 3, 5, and 7 are the single-equation results for the daily, weekly, and monthly estimations. The gasoline price elasticity of vehicle flows estimates are $-0.03,-0.04$, and -0.03 , to two decimal places.

Columns 2, 4, 6, and 8 of Table 3 show the IV results, in which the log real world crude oil price is used to instrument the log real gasoline price. The IV elasticities are similar to the OLS results. The significant first-stage coefficients suggest that the log world crude oil price is positively correlated with the log TGP, as expected. Specifically, a 1\% higher world crude oil price on average is associated with a $0.5 \%$ higher TGP, holding the other variables fixed. Stock and Yogo (2005) tests confirm that the log world crude oil price provides strong first-stage identification. 
Table 3 Results and IV estimates using hourly, daily, weekly and monthly data for 2010-2017

\begin{tabular}{|c|c|c|c|c|c|c|c|c|}
\hline \multicolumn{9}{|c|}{ Dependent variable: Ln traffic flow } \\
\hline \multirow[t]{3}{*}{ Specification } & \multicolumn{2}{|l|}{ Hourly } & \multicolumn{2}{|l|}{ Daily } & \multicolumn{2}{|l|}{ Weekly } & \multicolumn{2}{|l|}{ Monthly } \\
\hline & OLS & IV & OLS & IV & OLS & IV & OLS & IV \\
\hline & (1) & (2) & (3) & (4) & $(5)$ & $(6)$ & (7) & $(8)$ \\
\hline Ln Real gasoline price & $\begin{array}{l}-0.040 * * * \\
(0.002)\end{array}$ & $\begin{array}{l}-0.045^{* * *} \\
(0.002)\end{array}$ & $\begin{array}{l}-0.030 * * * \\
(0.003)\end{array}$ & $\begin{array}{l}-0.032 * * * \\
(0.003)\end{array}$ & $\begin{array}{l}-0.039 * * * \\
(0.005)\end{array}$ & $\begin{array}{l}-0.043 * * * \\
(0.005)\end{array}$ & $\begin{array}{l}-0.028 * * \\
(0.012)\end{array}$ & $\begin{array}{l}-0.015 \\
(0.013)\end{array}$ \\
\hline Ln S\&P/ASX 200 price & $\begin{array}{l}0.010 * * * \\
(0.002)\end{array}$ & $\begin{array}{l}0.011 * * * \\
(0.002)\end{array}$ & $\begin{array}{l}0.012 * * * \\
(0.003)\end{array}$ & $\begin{array}{l}0.012 * * * \\
(0.003)\end{array}$ & $\begin{array}{l}0.038 * * * \\
(0.007)\end{array}$ & $\begin{array}{l}0.038 * * * \\
(0.007)\end{array}$ & $\begin{array}{l}0.000 \\
(0.019)\end{array}$ & $\begin{array}{l}0.001 \\
(0.019)\end{array}$ \\
\hline Rainfall (mm) & $\begin{array}{l}-0.001 * * * \\
(0.000)\end{array}$ & $\begin{array}{l}-0.001 * * * \\
(0.000)\end{array}$ & $\begin{array}{l}-0.001 * * * \\
(0.000)\end{array}$ & $\begin{array}{l}-0.001 * * * \\
(0.000)\end{array}$ & $\begin{array}{l}-0.001 * * * \\
(0.000)\end{array}$ & $\begin{array}{l}-0.001 * * * \\
(0.000)\end{array}$ & $\begin{array}{l}-0.002 * * * \\
(0.001)\end{array}$ & $\begin{array}{l}-0.002 * * * \\
(0.001)\end{array}$ \\
\hline Maximum temperature $\left({ }^{\circ} \mathrm{C}\right)$ & $\begin{array}{l}0.002 * * * \\
(0.000)\end{array}$ & $\begin{array}{l}0.002 * * * \\
(0.000)\end{array}$ & $\begin{array}{l}0.001 * * * \\
(0.000)\end{array}$ & $\begin{array}{l}0.001 * * * \\
(0.000)\end{array}$ & $\begin{array}{l}0.001 * * * \\
(0.000)\end{array}$ & $\begin{array}{l}0.001 * * * \\
(0.000)\end{array}$ & $\begin{array}{l}-0.003 * * * \\
(0.001)\end{array}$ & $\begin{array}{l}-0.003 * * * \\
(0.001)\end{array}$ \\
\hline Public holiday & $\begin{array}{l}-0.182 * * * \\
(0.002)\end{array}$ & $\begin{array}{l}-0.181 * * * \\
(0.002)\end{array}$ & $\begin{array}{l}-0.182 * * * \\
(0.004)\end{array}$ & $\begin{array}{l}-0.182 * * * \\
(0.004)\end{array}$ & $\begin{array}{l}-0.007 * * * \\
(0.003)\end{array}$ & $\begin{array}{l}-0.007 * * * \\
(0.003)\end{array}$ & $\begin{array}{l}-0.001 \\
(0.004)\end{array}$ & $\begin{array}{c}-0.002 \\
(0.004)\end{array}$ \\
\hline School holiday & $\begin{array}{l}-0.018 * * * \\
(0.000)\end{array}$ & $\begin{array}{l}-0.018 * * * \\
(0.000)\end{array}$ & $\begin{array}{l}-0.023 * * * \\
(0.001)\end{array}$ & $\begin{array}{l}-0.023 * * * \\
(0.001)\end{array}$ & $\begin{array}{l}0.004 * * * \\
(0.001)\end{array}$ & $\begin{array}{l}0.004 * * * \\
(0.001)\end{array}$ & $\begin{array}{c}-0.001 \\
(0.001)\end{array}$ & $\begin{array}{c}-0.001 \\
(0.001)\end{array}$ \\
\hline Double demerit period & $\begin{array}{l}-0.018 * * * \\
(0.001)\end{array}$ & $\begin{array}{l}-0.018 * * * \\
(0.001)\end{array}$ & $\begin{array}{l}-0.018 * * * \\
(0.001)\end{array}$ & $\begin{array}{l}-0.018 \text { *** } \\
(0.001)\end{array}$ & $\begin{array}{l}0.048 * * * \\
(0.004)\end{array}$ & $\begin{array}{l}0.048 * * * \\
(0.004)\end{array}$ & - & - \\
\hline Unemployment rate $(\%)$ & - & - & - & - & - & - & $\begin{array}{l}-0.008 * * \\
(0.003)\end{array}$ & $\begin{array}{l}-0.009 * * * \\
(0.003)\end{array}$ \\
\hline Hour-of-day dummies & Yes & Yes & No & No & No & No & No & No \\
\hline Day-of-week dummies & Yes & Yes & Yes & Yes & No & No & No & No \\
\hline Within- $R^{2}$ & 0.82 & 0.82 & 0.31 & 0.31 & 0.08 & 0.08 & 0.19 & 0.19 \\
\hline Observations & $11,788,050$ & $11,788,050$ & 485,185 & 485,185 & 58,692 & 58,692 & 5,922 & 5,922 \\
\hline Instrumented variable: $\mathrm{Ln}$ & e price (ce & liter). Instru & 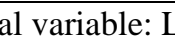 & l world cru & price (cer & & & \\
\hline Coefficient on instruments & & $0.474 * * *$ & & $0.464 * * *$ & & $0.467 * * *$ & & $0.453 * * *$ \\
\hline$F$ statistic on instrument & & $42,000,000$ & & $1,700,000$ & & 210,000 & & 26,548 \\
\hline
\end{tabular}

Notes: Coefficients for constants, new clearway dummy, and daylight saving doubled-up hour term are not reported. $* * *, * *$, and $*$ indicate statistical significance at $1 \%, 5 \%$, and $10 \%$ respectively. Non-clustered but robust standard errors are shown in parentheses for all columns as it is beyond Stata's capacity to compute cluster-robust standard errors in the hourly IV estimations. The null of weak instruments is rejected if the $F$ statistic on the instruments exceeds the Stock-Yogo critical value. The Stock-Yogo 5\% critical value for 10\% maximal IV size is 16.38. Some stations are for either direction on the same road. All columns control for month-of year dummies, station fixed effects, and a time trend. In the monthly estimation, the double demerit period term is dropped to avoid perfect collinearity with the month-of-year dummies. 
The positive coefficients for the log S\&P/ASX 200 price in Table 3 suggest that traffic flows are on average higher when there is confidence in the economy. The coefficients for rainfall are negative and significant at the $1 \%$ level, likely to be because people reduce driving in wet weather. The higher the maximum temperature, the greater the traffic flow (all else equal), perhaps because people are more likely to go out when it is warmer. The public holiday dummy and school holiday dummy are negative and significant, presumably because fewer people are commuting to work and school on these days. A negative coefficient is found for the double demerit period variable. There is also a negative coefficient for the unemployment rate in the monthly estimation, suggestive of labor market conditions having a material effect on road traffic flows.

Some vehicles run on diesel rather than gasoline. Table A2 in the Appendix presents results using the weighted average of the gasoline and diesel prices. ${ }^{7}$ The coefficients for the log real average fuel price remain similar to those using the log real gasoline price.

Coefficients for the monthly, weekly, and hourly dummies are reported in Table A3 in the Appendix. All monthly dummy variables except the May, June, July, and August dummies are positive, indicating higher traffic flows than January (the base month). Traffic flows are particularly high during December, a 31-day month when there are many events on and the weather is favorable. All of the day-of-week dummy variables are statistically significant, indicating strong daily variation in the data. The hour-of-day dummy coefficients are higher during the day than in the late evening or very early morning hours, as expected.

Durbin-Wu-Hausman tests (Durbin 1954; Wu 1973; Hausman 1978) were conducted for the daily, weekly, and monthly estimations to detect if the gasoline price should be treated as endogenous. ${ }^{8}$ The null hypothesis that the gasoline price is exogenous cannot be rejected at the $5 \%$ level. This reflects the fact that the results are similar with or without the instrument. Given the efficiency advantage of OLS, OLS estimations are pursued for most of the forthcoming estimates.

Table 4 presents a robustness check for the monthly estimates. Column 1 includes a lagged dependent variable. Column 2 uses the average gasoline unleaded pump price from Fueltrac (2018). The elasticities remain quite similar, and are significantly different from zero. The point estimate for the log real gasoline price in column 2 is slightly larger than the coefficient in column 7 of Table 3 . This is expected as the pump price is higher than the TGP given the additional margins that are included in final retail prices.

\footnotetext{
${ }^{7}$ In 2017, petrol vehicles comprised about $75 \%$ of the stock of motor vehicles in Australia, compared to $23 \%$ for diesel vehicles and 2\% for others (Australian Bureau of Statistics 2018). Weights of 0.75 for gasoline vehicles and 0.25 for diesel vehicles are applied. Time trends of gasoline and diesel prices are similar.

${ }^{8}$ The Durbin-Wu-Hausman test is not conducted for the hourly estimations because the sample size exceeds the capacity of Stata to compute the test.
} 
Table 4 Monthly results using other specifications

\begin{tabular}{|c|c|c|}
\hline \multirow[t]{2}{*}{ Specification } & \multirow{2}{*}{$\begin{array}{l}\text { Lagged dependent } \\
\text { variable } \\
(1) \\
\end{array}$} & \multirow{2}{*}{$\begin{array}{l}\text { Gasoline pump price } \\
\text { (2) }\end{array}$} \\
\hline & & \\
\hline Ln Real gasoline price & $\begin{array}{c}-0.023^{*} \\
(0.013)\end{array}$ & - \\
\hline Ln Real gasoline pump price & - & $\begin{array}{c}-0.035^{*} \\
(0.019)\end{array}$ \\
\hline Ln S\&P/ASX 200 price & $\begin{array}{l}-0.007 \\
(0.014)\end{array}$ & $\begin{array}{l}-0.002 \\
(0.024)\end{array}$ \\
\hline Rainfall (mm) & $\begin{array}{l}-0.003 * * * \\
(0.000)\end{array}$ & $\begin{array}{l}-0.002 * * * \\
(0.000)\end{array}$ \\
\hline Maximum temperature $\left({ }^{\circ} \mathrm{C}\right)$ & $\begin{array}{l}-0.005^{* * * *} \\
(0.001)\end{array}$ & $\begin{array}{l}-0.003 * * * \\
(0.001)\end{array}$ \\
\hline Public holiday & $\begin{array}{l}-0.010 * * * \\
(0.003)\end{array}$ & $\begin{array}{l}-0.001 \\
(0.004)\end{array}$ \\
\hline School holiday & $\begin{array}{l}0.002 * * * \\
(0.001)\end{array}$ & $\begin{array}{l}-0.001 \\
(0.001)\end{array}$ \\
\hline Unemployment rate (\%) & $\begin{array}{l}-0.008 * * \\
(0.003)\end{array}$ & $\begin{array}{l}-0.008 * \\
(0.005)\end{array}$ \\
\hline New clearway dummy & $\begin{array}{l}-0.005 \\
(0.004)\end{array}$ & $\begin{array}{l}0.015 \\
(0.017)\end{array}$ \\
\hline Ln Traffic flow $_{t-1}$ & $\begin{array}{l}0.920 * * * \\
(0.019)\end{array}$ & - \\
\hline Within- $R^{2}$ & 0.85 & 0.19 \\
\hline Observations & 1,636 & 5,922 \\
\hline $\begin{array}{l}\text { Notes: Coefficients for cons } \\
\text { significant at } 1 \%, 5 \% \text {, and } 10 \\
\text { time-varying explanatory } \\
\text { parentheses. Both regressic } \\
\text { month-of year dummies, stat } \\
\text { dummies and day-of-week } \\
\text { dummy is dropped to avoid p } \\
\text { sample size reduces when lag }\end{array}$ & $\begin{array}{l}\text { nts are not reported. } \\
\text { respectively. The u } \\
\text { ariables. Cluster-rob } \\
\text { is use OLS estimatic } \\
\text { n fixed effects, and } \\
\text { lummies are not incl } \\
\text { rfect collinearity wit } \\
\text { ed traffic flow is inc }\end{array}$ & $\begin{array}{l}* \text {, and } * \text { indicate statistical } \\
2 \text { measures the power of the } \\
\text { dard errors are shown in } \\
\text { thly data, and control for } \\
\text { ly time trend. Hour-of-day } \\
\text { he double demerit period } \\
\text { onth-of-year dummies. The } \\
\text { s a result of missing values. }\end{array}$ \\
\hline
\end{tabular}

\subsection{Peak versus off-peak periods}

NSW Roads and Maritime Services (2019a) defines peak periods as 6-10am and 3-7pm of every day of the week. Figure 4 shows the distributions of average daily traffic flows on weekdays and weekends. On weekdays, traffic flows indeed rise to a peak during 6-10am and 3-7pm, and a lower level in the middle of the day and at night. On weekends, however, traffic is quite consistent throughout the day. The weekend peak period is thus defined as $9 \mathrm{am}-6 \mathrm{pm}$ in the analysis in this sub-section.

Table 5 reports the elasticities for different times of the week. Weekdays and weekends are compared first, using an interaction between the log real gasoline price and a weekday dummy and a second interaction (in the same regression) between the log real gasoline price and a weekend dummy. The coefficient for the $\log$ real gasoline price is -0.040 for weekdays and 0.038 for weekends, with both significantly different from zero at the $5 \%$ level. The null hypothesis that the elasticity for weekends equals the elasticity for weekdays cannot be rejected. 
This suggests that the average influence of gasoline prices on hourly traffic flows does not vary much by weekday or weekend.

Figure 4 Distribution of average hourly traffic flow

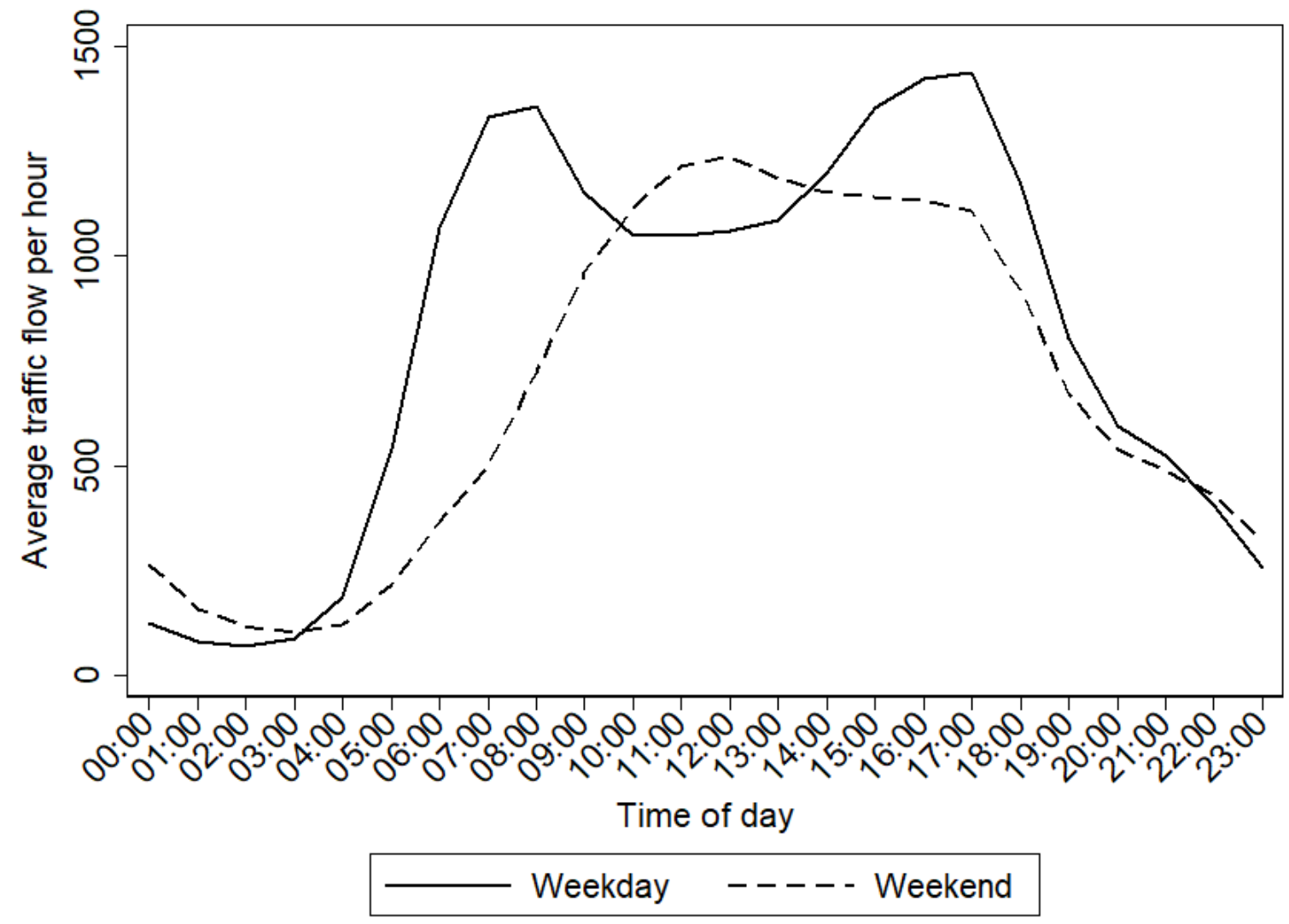

Source: NSW Roads and Maritime Services (2019a). Notes: The traffic flow within each hour is the average of all stations' hourly data. The graph uses a balanced sample of stations.

Next, peak-period elasticities are compared with off-peak elasticities for both weekdays and weekends. The estimates were obtained by including four interacted terms in a single regression - interactions between the log real gasoline price and: the weekday peak dummy, weekday off-peak dummy, weekend peak dummy, and weekend off-peak dummy. Interestingly, the estimated elasticity for weekday peak periods is 0.064 , significantly different from zero at the $1 \%$ level. This positive coefficient is consistent with an increase in traffic flows when the fuel price increases, likely due to the easing of hypercongested conditions. Estimates for off-peak periods are negative and statistically significant.

Figure 5 graphs the gasoline price elasticities by time of day on both weekdays and weekends. These elasticities are obtained by interacting the log real gasoline price term with weekday/weekend dummies and hour-of-day dummies. The largest negative estimated elasticities occur during the early morning. The overall patterns are quite similar for weekdays and weekends. It can be seen that the positive and significant weekday effects hold for both morning peak and especially afternoon peak hours. 
Table 5 Results for peak and off-peak periods

\begin{tabular}{|c|c|c|c|c|c|c|}
\hline \multicolumn{7}{|c|}{ Dependent variable: Ln traffic flow } \\
\hline \multirow{3}{*}{ Period } & Weekday & & & Weekend & & \\
\hline & All day & Peak & Off-peak & All day & Peak & Off-peak \\
\hline & (1) & (2) & $(3)$ & (4) & (5) & $(6)$ \\
\hline Ln real gasoline price & $\begin{array}{l}-0.040 * * \\
(0.017)\end{array}$ & $\begin{array}{l}0.064 * * * \\
(0.023)\end{array}$ & $\begin{array}{l}-0.103 * * * \\
(0.018) \\
{[0.000]}\end{array}$ & $\begin{array}{l}-0.038 * * \\
(0.017) \\
{[0.796]}\end{array}$ & $\begin{array}{l}0.022 \\
(0.026)\end{array}$ & $\begin{array}{l}-0.074 * * * \\
(0.020) \\
{[0.002]}\end{array}$ \\
\hline
\end{tabular}

Notes: Coefficients for controls and constants are not reported. ***,**, and * indicate statistical significant at $1 \%, 5 \%$, and $10 \%$ respectively. Cluster-robust standard errors are shown in parentheses. There are two regressions in this table: the results in columns 1 and 4 are from a single regression, and the other results are from a separate regression. All regressions use OLS estimation and hourly data. The figure in square brackets in column 3 is the $p$-value for a test of equality to the coefficient in column 2 . That in column 4 is the $p$-value for a test of equality to the coefficient in column 1 . That in column 6 is the $p$-value for a test of equality to the coefficient in column 5 .

Taken together, the results indicate that higher gasoline prices on average lead to a reduction in traffic flows and that they lead to an increase in traffic flow in some peak periods. The latter finding is consistent with an alleviation of peak-period hypercongestion, which allows more vehicles to flow past a given point during an hour. As mentioned, data on density are unfortunately not available to directly test the effect of gasoline prices on congestion levels.

Burger and Kaffine (2009) found that peak-hour speeds increase when gasoline prices rise in Los Angeles, presumably because roads become less congested so the traffic can flow more smoothly. To test if the same is true for NSW, average space-mean peak-hour vehicle speed data were obtained for NSW roads from the NSW Roads and Maritime Services (2019b). The dataset covers 119 major roads. The data are only available on a monthly basis for October 2018-June 2019 and average speeds are only available for the morning and afternoon peak periods (separately) according to the definition of the NSW Roads and Maritime Services (2019a). The following equation is estimated for both morning and afternoon peak periods:

$\ln S_{c, t}=\beta_{0}+\beta_{1} \ln P_{t}+\beta_{2} U_{t}+\beta_{3} D_{t}+R_{i}+\beta_{4} J_{1}+\beta_{5} J_{2}+\beta_{6} J_{3}+\varepsilon_{c, t}$

where $S$ is the average space-mean speed for road $i$ in month $t ; P$ is the real gasoline price; $U$ is the unemployment rate; $C$ is the consumer confidence index $(\mathrm{CCI}) ;{ }^{9} R$ represents road fixed effects; and $\varepsilon$ is an error term. Given that data are available for less than one year, a full set of month-of-year dummies cannot be controlled for as otherwise there would be an issue of perfect collinearity. According to Table A3 in the Appendix, traffic flows tend to be lower in January, May, and June than in other months, which may affect speeds. Separate dummy variables $\left(J_{1}, J_{2}, J_{3}\right)$ are included for these three months. A time trend is not included given the short time-span.

The results are shown in Table 6. The gasoline price elasticity of average vehicle travel speed is found to be 0.25 for the afternoon peak period, an effect that is significantly different from zero. This is consistent with a conclusion that a higher gasoline price leads to a lowering of traffic density at hypercongested times, which permits higher vehicle flow numbers. No

\footnotetext{
${ }^{9}$ Because monthly CCI data for NSW are unavailable, the Australian CCI is used instead.
} 
significant effect is found for the morning peak period. As additional data become available it would be interesting to confirm the findings for this speed analysis.

Figure 5 Effect of gasoline prices changes on traffic flow, by time of day

(a) Weekday

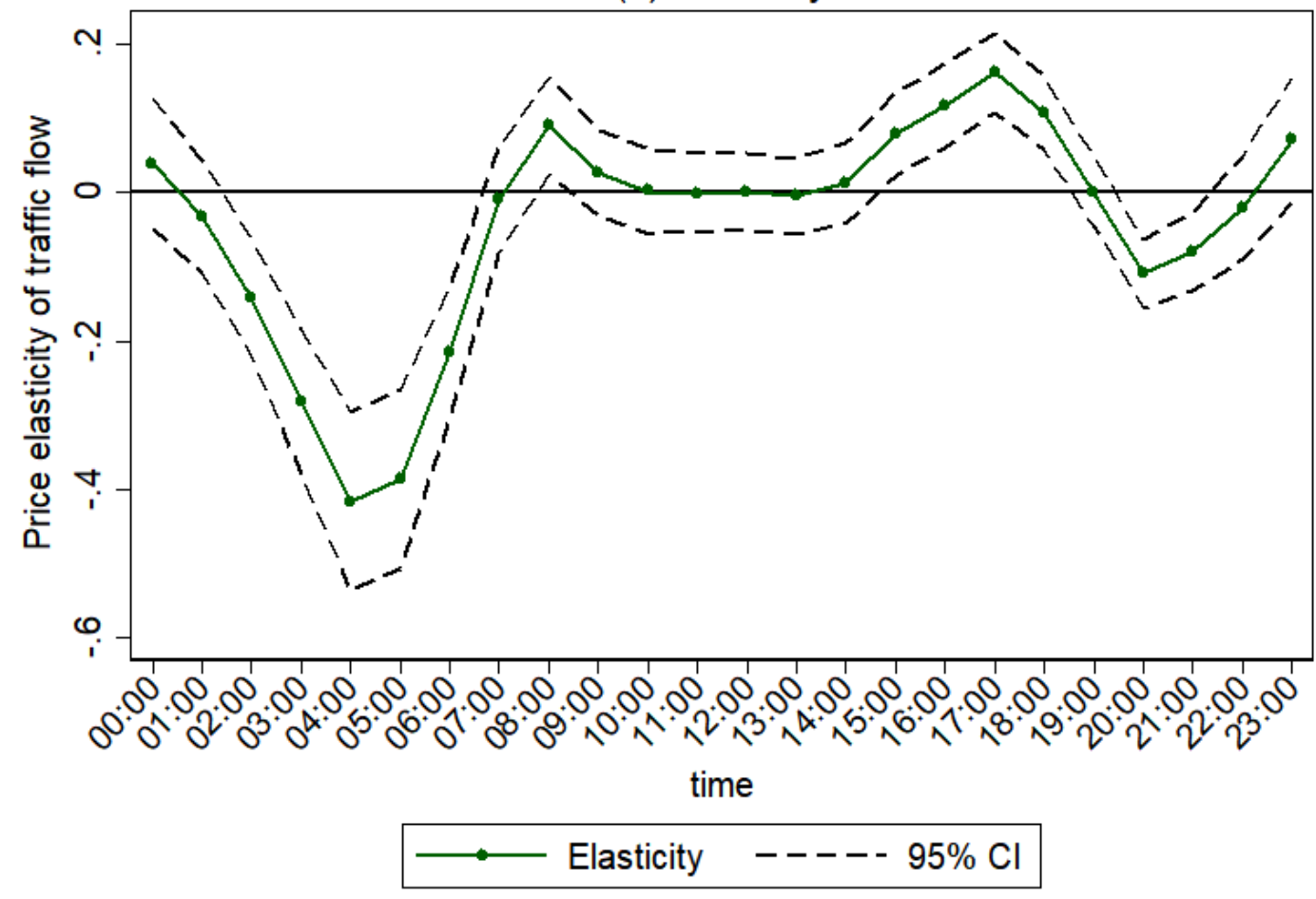

(b) Weekend

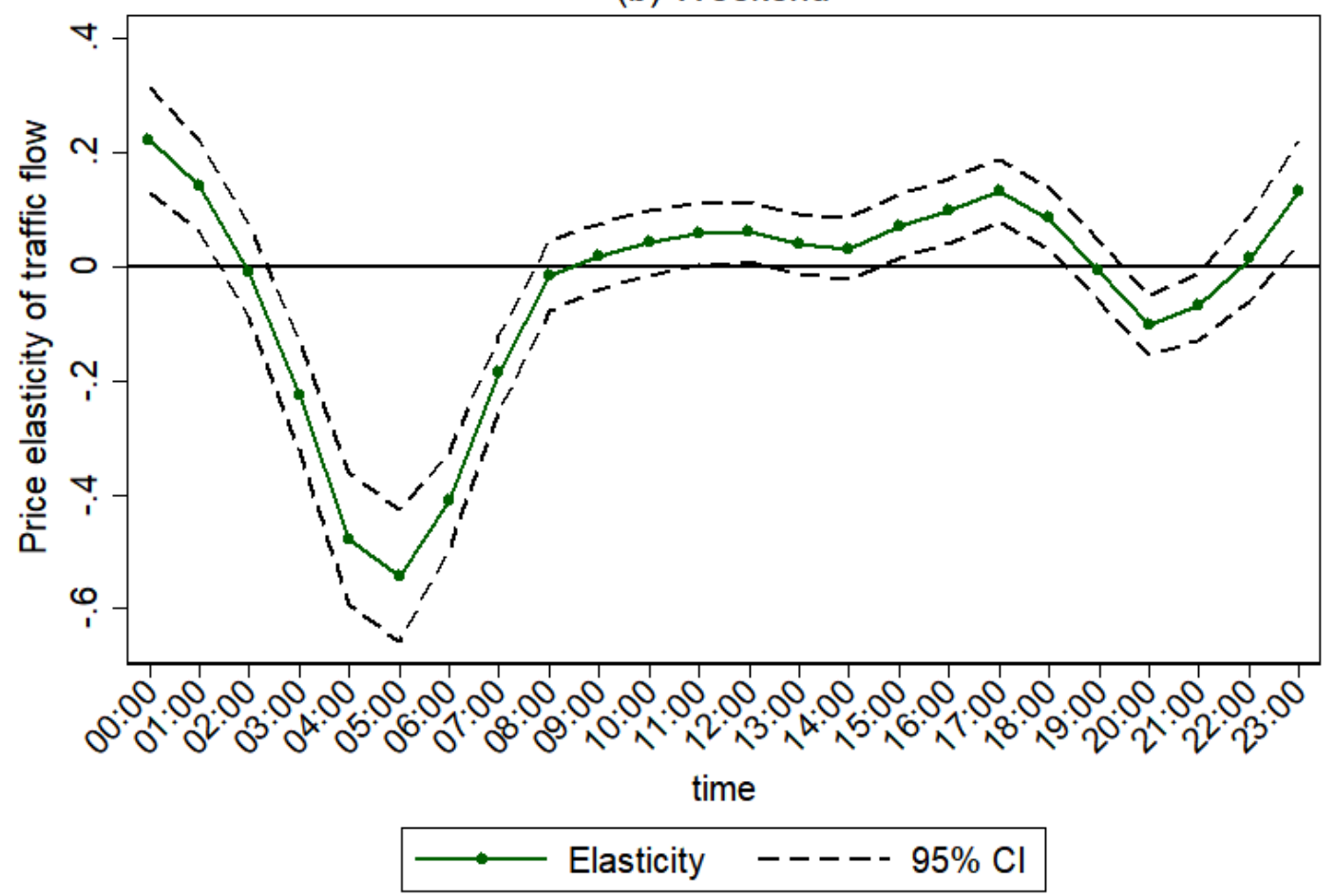

Source: NSW Roads and Maritime Services (2019a). Notes: The regression uses hourly data. 
Table 6 Elasticities for peak-period average speed with respect to the gasoline price Dependent variable: $\mathrm{Ln}$ average speed

\begin{tabular}{lll}
\hline & Morning peak period & Afternoon peak period \\
\cline { 2 - 3 } & $(1)$ & $(2)$ \\
\hline Ln gasoline price (real) & -0.066 & $0.250^{* * *}$ \\
& $(0.104)$ & $(0.035)$ \\
Unemployment rate (\%) & 0.036 & -0.014 \\
& $(0.062)$ & $(0.035)$ \\
Consumer confidence index & 0.003 & -0.001 \\
& $(0.002)$ & $(0.001)$ \\
January dummy & Yes & Yes \\
May dummy & Yes & Yes \\
June dummy & Yes & Yes \\
Within- $R^{2}$ & 0.19 & 0.28 \\
Observations & 1,071 & 1,071 \\
\hline
\end{tabular}

Notes: Coefficients for constants are not reported. ***, **, and * indicate statistical significant at $1 \%, 5 \%$, and $10 \%$ respectively. The within- $R^{2}$ measures the power of the time-varying explanatory variables. Cluster-robust standard errors are shown in parentheses. All regressions use OLS estimation and monthly data.

\subsection{Station-level heterogeneity}

Potential station-level heterogeneity in the gasoline price elasticity of traffic flow is now investigated, using a similar interaction approach to that used in Table 5. All interaction component terms are controlled for separately in each regression. ${ }^{10}$ The results are presented in Table 7. Results of statistical tests of parameters equality are also shown.

Whether geography is a factor is investigated by comparing elasticities in Greater Sydney versus outside Greater Sydney. The results in panel A of Table 7 indicate that the elasticities for these two areas are similar, and the $p$-value for a test of equality of coefficients for these two groups equals 0.96. Panel B shows elasticity estimates for roads in and outside the Sydney CBD. A negative and statistically significant coefficient is obtained for outside the Sydney $\mathrm{CBD}$, while an insignificant estimate is obtained for the CBD. The null hypothesis that the two parameters are equal cannot be rejected. The finding contrasts to that of Bento et al. (2013), who found that drivers' responsiveness to gasoline prices in Los Angeles is more elastic at locations further from the downtown area. Note however that the sample of count stations in the Sydney CBD is small. There are two count stations in the CBD: the Sydney Harbour Tunnel and the Cahill Expressway.

\footnotetext{
${ }^{10}$ In panel A of Table 6, an interaction between the log real gasoline price and the Greater Sydney dummy and an interaction between the log real gasoline price and outside greater Sydney dummy are included in the same regression. Panels B, C, and D follow the same type of approach.
} 
Figure 6 Gasoline price elasticity of traffic flow and 95\% confidence intervals

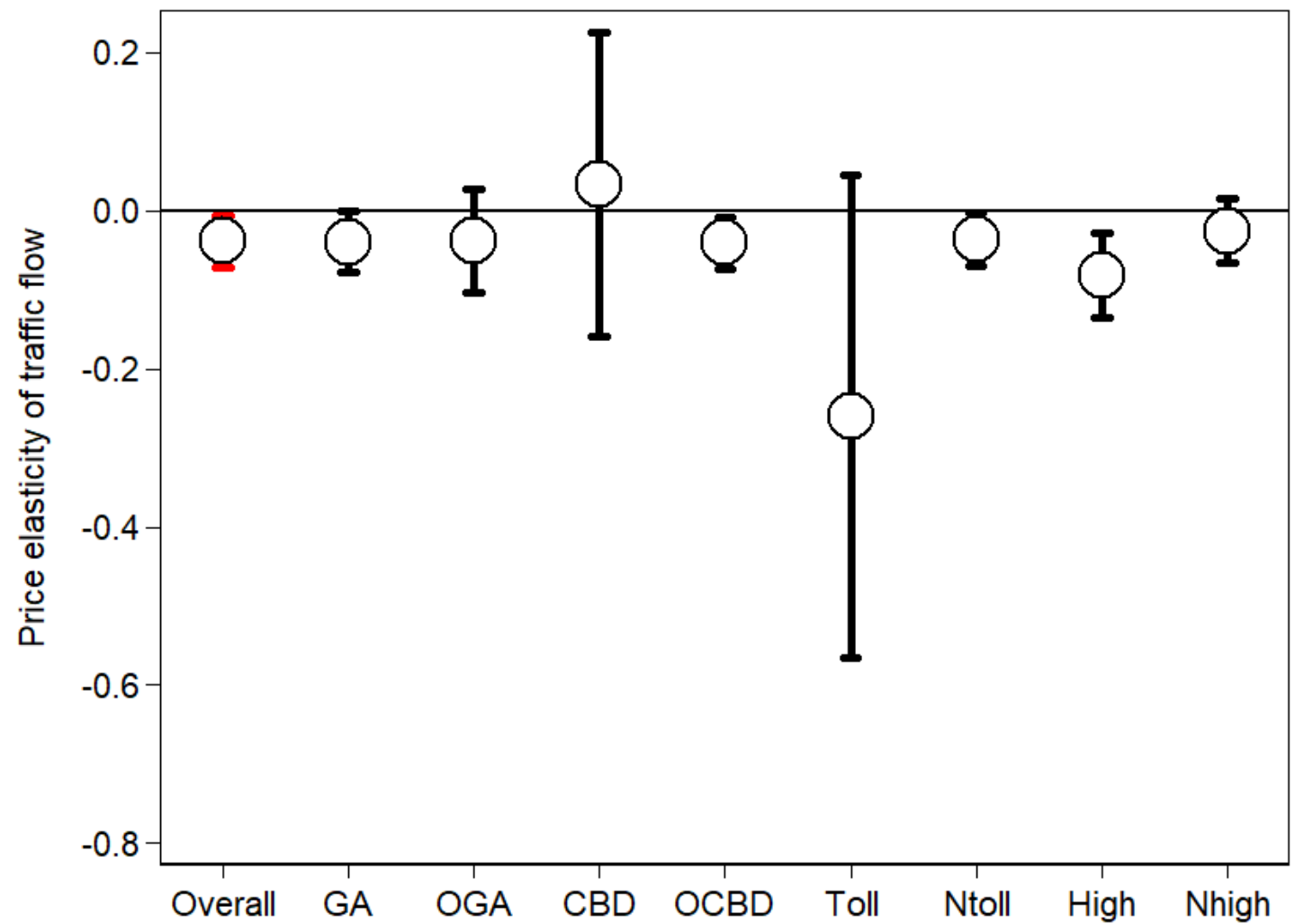

Notes: These are the estimates from Table 7. GA = Great Sydney area. OGA $=$ Outside greater Sydney. CBD = Sydney CBD. OCBD = Outside Sydney CBD. Toll $=$ Toll roads. Ntoll = Non-toll roads. High = Highways Nhigh $=$ Non-highways.

\subsection{Medium-run elasticities}

To explore the medium-run responses of traffic flows to gasoline price changes, a distributed lag model is used, with lags back to day $t-120$ (Table 8). The medium-run elasticity is the sum of the coefficients for each gasoline price term. The sample size reduces when adding lagged terms. Column 5 provides an estimate of the medium-run elasticity of -0.034 . This is similar to the short-run effect obtained in column $1(-0.030)$. Hence there is not much evidence of a lagged effect. While the long-run effect is likely to be larger than the immediate effect because it takes time to know that prices have changed and to fully respond (Musso et al. 2013), 120 days of lag may not be sufficient to allow this process to fully play out. 
Table 8 Medium-run elasticities

\begin{tabular}{|c|c|c|c|c|c|}
\hline \multicolumn{6}{|c|}{ Dependent variable: Ln traffic flow $_{t}$} \\
\hline & $(1)$ & $(2)$ & (3) & (4) & $(5)$ \\
\hline Ln Real gasoline price ${ }_{t}$ & $\begin{array}{l}-0.030 * * \\
(0.015)\end{array}$ & $\begin{array}{l}0.009 \\
(0.016)\end{array}$ & $\begin{array}{l}0.006 \\
(0.014)\end{array}$ & $\begin{array}{l}0.018 \\
(0.016)\end{array}$ & $\begin{array}{l}0.017 \\
(0.016)\end{array}$ \\
\hline Ln Real gasoline price $_{t-30}$ & & $\begin{array}{l}-0.044 * * * \\
(0.014)\end{array}$ & $\begin{array}{l}-0.026 * * * \\
(0.010)\end{array}$ & $\begin{array}{l}-0.053 * * * \\
(0.010)\end{array}$ & $\begin{array}{l}-0.068 * * * \\
(0.010)\end{array}$ \\
\hline Ln Real gasoline price ${ }_{t-60}$ & & & $\begin{array}{l}-0.014 \\
(0.016)\end{array}$ & $\begin{array}{l}0.038 * * * \\
(0.011)\end{array}$ & $\begin{array}{l}0.054 * * * \\
(0.012)\end{array}$ \\
\hline Ln Real gasoline price t $-90_{0}$ & & & & $\begin{array}{l}-0.043 * * * \\
(0.015)\end{array}$ & $\begin{array}{l}-0.040 * * * \\
(0.011)\end{array}$ \\
\hline Ln Real gasoline price ${ }_{t-120}$ & & & & & $\begin{array}{l}0.003 \\
(0.014)\end{array}$ \\
\hline Within- $R^{2}$ & 0.31 & 0.36 & 0.36 & 0.37 & 0.37 \\
\hline Observations & 485,185 & 422,032 & 367,670 & 322,394 & 283,842 \\
\hline Medium-run elasticity & $-0.030 * * *$ & $-0.034 * *$ & $-0.034 *$ & $-0.040 * *$ & $-0.034 * * *$ \\
\hline
\end{tabular}

Notes: Coefficients for controls are not reported. $* * *, * *$, and $*$ indicate statistical significance at $1 \%, 5 \%$, and $10 \%$ respectively. Cluster-robust standard errors are shown in parentheses. The within- $R^{2}$ measures the power of the time-varying explanatory variables. All regressions use OLS estimation, daily data, and control for day-of-week dummies, month-of year dummies, station fixed effects, and a daily time trend. Hour-of-day dummies are not included. The medium-run elasticity is the sum of the coefficients for each price term.

\section{Effects of gasoline prices on gasoline use and public transport ridership}

\subsection{Price elasticity of gasoline demand}

It is expected that the gasoline own-price elasticity of demand is larger than the gasoline price elasticity of vehicle traffic flow, as there are additional responses to higher gasoline prices than only reducing driving. These include changing driving speed or styles and shifting to more fuel-efficient vehicles (Kennedy and Wallis 2007). The gasoline price elasticity of vehicle flows is also pushed towards being highly inelastic because a higher gasoline price increases vehicle flows when road conditions would otherwise have been hypercongested. In order to investigate the effect of gasoline price increases on total gasoline use by the road sector, Eq (4) is estimated using monthly data for July 2010-December 2017:

$\ln S_{t}=\alpha_{0}+\alpha_{1} \ln P_{t}+\alpha_{2} U_{t}+\alpha_{3} C_{t}+\alpha_{4} T_{t}+D_{m: y}+\varepsilon_{t}$

$S$ is sales of automotive gasoline in month $t ; P$ is the monthly real TGP; $U$ is the unemployment rate; $C$ is the Australian CCI; $T$ is a linear time trend; $D$ is a set of month-ofyear effects; and $\varepsilon$ is an error term.

An Augmented Dickey-Fuller test was first carried out. The results suggest that the log gasoline sales and CCI data are stationary. Estimations are thus again carried out in levels rather than first differences.

Column 1 of Table 9 finds an estimate of the gasoline own-price elasticity of demand of around -0.11 , indeed larger than the estimates of the gasoline price elasticity of traffic flow. Column 2 shows the IV result using the log real world crude oil price to instrument the log real gasoline price. The point estimate is slightly larger than the OLS result. A Stock and Yogo (2005) test confirms that the log world crude oil price provides strong first-stage identification. A Durbin$\mathrm{Wu}-$ Hausman test cannot reject the null hypothesis that the gasoline price is exogenous. 
Table 9 Elasticities for gasoline sales for July 2010-December 2017

\begin{tabular}{lll}
\hline \multicolumn{2}{l}{ Dependent variable: Ln gasoline sales (megaliters) } & IV \\
\cline { 2 - 3 } & OLS & $(2)$ \\
\hline Ln real gasoline price & $-0.109^{* * *}$ & $-0.124^{* * *}$ \\
Unemployment rate (\%) & $(0.033)$ & $(0.035)$ \\
& $-0.035^{* * *}$ & $-0.034^{* * *}$ \\
Consumer confidence index & $(0.006)$ & $(0.006)$ \\
& -0.001 & -0.001 \\
Month-of-year dummies & $(0.001)$ & $(0.001)$ \\
Time trend & Yes & Yes \\
Adjusted $R^{2}$ & Yes & Yes \\
Observations & 0.75 & 0.75 \\
\hline
\end{tabular}

Instrumented variable: Ln real Gasoline price. Instrumental variable: Ln real world crude oil price.

Coefficient on instruments $0.412 * * *$

$F$ statistic on instrument $\quad 307.88$

Notes: Coefficient for constant is not reported. $* * *, * *$, and $*$ indicate statistical significant at $1 \%$, $5 \%$, and $10 \%$ respectively. Robust standard errors are shown in parentheses. The null of weak instruments is rejected if the $F$ statistic on the instruments exceeds the Stock-Yogo critical value. The Stock-Yogo 5\% critical value for $10 \%$ maximal IV size is 16.38 .

\subsection{Gasoline price-public transport ridership elasticity}

A higher gasoline price may induce substitution to public transport. Austin (2008) found that higher gasoline prices are indeed associated with greater ridership on transit rail systems in California. Rohani and Pahazri (2018) conducted a survey in Malaysia by distributing questionnaires to private vehicle users, finding that many respondents stated that they reduce the frequency of vehicle use or shift to public transport after increases in fuel prices.

To investigate if higher gasoline prices motivate people to switch to public transport, the following model is estimated using available monthly data for July 2016-December 2018:

$$
\ln B_{t}=\beta_{0}+\beta_{1} \ln P_{t}+\beta_{2} U_{t}+\beta_{3} C_{t}+D_{m: y}+\varepsilon_{t}
$$

$B$ is the official utilization figure across all public transport modes (train, bus, ferry, and light rail) based on people using an Opal tap card in NSW in month $t$; $P$ is the monthly real TGP; $U$ is the unemployment rate; $C$ is the Australian CCI; $D$ is a set of month-of-year effects; and $\varepsilon$ is an error term. A time trend is not included given the short time-span of data.

The Opal card is the smart tap-on and tap-off card that is used for public transport in NSW. Since 1 August 2016, paper tickets have no longer been accepted, with the Opal card being the only ticketing option available (Raper 2016). The Opal card tap-on figures quite accurately represent public transport ridership. ${ }^{12}$ The model does not control for Opal fares, which remained constant over the period.

\footnotetext{
${ }^{12}$ Non-Opal travel includes integrated ticketing for major events, transport concession entitlement cards, and fare non-compliance. This is a small proportion of total public transport usage.
} 
Table 10 reports the gasoline price-public transport ridership elasticity for different modes. Because the results of unit root tests are similar to those for Eq (2), level variables are again used. The elasticity for total public transport utilization in column 1 is 0.28 , significant at the $1 \%$ level. This suggests that an increase in gasoline price indeed tends to encourage people to use public transport. The elasticity for train utilization is 0.35 (column 3 ). This relatively high elasticity might be explained by the fact that trains have a higher proportion of longer distance trips, whereas buses and light rail are generally used for shorter trips for which the fuel costs of driving are a smaller consideration. It should be noted that the sample sizes are quite small for these public transport regressions.

IV results using the log real world crude oil price to instrument the log real gasoline price in Table 10 are again similar to the OLS results. The Stock and Yogo (2005) test confirms that the log world crude oil price provides strong first-stage identification. Durbin-Wu-Hausman tests cannot reject the null hypotheses that the gasoline price is exogenous for all 5 dependent variables. 
Table 10 Elasticities for public transport utilization for July 2016-December 2018

Dependent variable: Ln Opal card utilization

\begin{tabular}{|c|c|c|c|c|c|c|c|c|c|c|}
\hline & \multicolumn{2}{|l|}{ Total } & \multicolumn{2}{|l|}{ Train } & \multicolumn{2}{|l|}{ Bus } & \multicolumn{2}{|l|}{ Light rail } & \multicolumn{2}{|l|}{ Ferry } \\
\hline & OLS & IV & OLS & IV & OLS & IV & OLS & IV & OLS & IV \\
\hline & (1) & (2) & (3) & (4) & (5) & (6) & (7) & (8) & (9) & $(10)$ \\
\hline Ln real gasoline price & $\begin{array}{l}0.277 * * * \\
(0.059)\end{array}$ & $\begin{array}{l}0.275 * * * \\
(0.061)\end{array}$ & $\begin{array}{l}0.348 * * * \\
(0.069)\end{array}$ & $\begin{array}{l}0.343 * * * \\
(0.072)\end{array}$ & $\begin{array}{l}0.207 * * * \\
(0.057)\end{array}$ & $\begin{array}{l}0.211 * * * \\
(0.058)\end{array}$ & $\begin{array}{l}0.216 \\
(0.197)\end{array}$ & $\begin{array}{l}0.137 \\
(0.175)\end{array}$ & $\begin{array}{c}-0.112 \\
(0.146)\end{array}$ & $\begin{array}{c}-0.129 \\
(0.146)\end{array}$ \\
\hline Unemployment rate $(\%)$ & $\begin{array}{l}-0.066 * * * \\
(0.021)\end{array}$ & $\begin{array}{l}-0.066 * * * \\
(0.021)\end{array}$ & $\begin{array}{l}-0.068 * * * \\
(0.023)\end{array}$ & $\begin{array}{l}-0.068 * * * \\
(0.023)\end{array}$ & $\begin{array}{l}-0.063 * * \\
(0.022)\end{array}$ & $\begin{array}{l}-0.063 * * \\
(0.022)\end{array}$ & $\begin{array}{l}-0.184 * * * \\
(0.059)\end{array}$ & $\begin{array}{l}-0.195^{* *} \\
(0.067)\end{array}$ & $\begin{array}{l}0.003 \\
(0.025)\end{array}$ & $\begin{array}{l}0.001 \\
(0.026)\end{array}$ \\
\hline Consumer confidence index & $\begin{array}{l}0.001 \\
(0.002)\end{array}$ & $\begin{array}{l}0.001 \\
(0.002)\end{array}$ & $\begin{array}{c}-0.001 \\
(0.002)\end{array}$ & $\begin{array}{c}-0.001 \\
(0.002)\end{array}$ & $\begin{array}{l}0.004 * * \\
(0.002)\end{array}$ & $\begin{array}{l}0.004 * * \\
(0.002)\end{array}$ & $\begin{array}{c}-0.008 \\
(0.009)\end{array}$ & $\begin{array}{c}-0.007 \\
(0.008)\end{array}$ & $\begin{array}{l}0.004 \\
(0.003)\end{array}$ & $\begin{array}{l}0.004 \\
(0.003)\end{array}$ \\
\hline Month-of-year dummies & Yes & Yes & Yes & Yes & Yes & Yes & Yes & Yes & Yes & Yes \\
\hline Adjusted $R^{2}$ & 0.91 & 0.91 & 0.88 & 0.88 & 0.93 & 0.93 & 0.74 & 0.74 & 0.87 & 0.87 \\
\hline Observations & 30 & 30 & 30 & 30 & 30 & 30 & 30 & 30 & 30 & 30 \\
\hline \multicolumn{11}{|c|}{ Instrumented variable: Ln real Gasoline price (cents/liter). Instrumental variable: Ln real world crude oil price (cents/liter). } \\
\hline Coefficient on instruments & & $0.542 * * *$ & & $0.542 * * *$ & & $0.542 * * *$ & & $0.542 * * *$ & & $0.549 * * *$ \\
\hline$F$ statistic on instrument & & 661.01 & & 661.01 & & 661.01 & & 661.01 & & 661.01 \\
\hline
\end{tabular}

Notes: Coefficients for constants are not reported. $* * *, * *$, and $*$ indicate statistical significant at $1 \%, 5 \%$, and $10 \%$ respectively. Robust standard errors are shown in parentheses. The null of weak instruments is rejected if the $F$ statistic on the instruments exceeds the Stock-Yogo critical value. The Stock-Yogo $5 \%$ critical value for $10 \%$ maximal IV size is 16.38 


\section{Relating the results to prior studies}

Among prior studies on the effect of fuel prices on traffic flows, Bento et al. (2013) found fuel price elasticities of traffic flows of -0.083 and -0.050 for highways with and without a carpool lane using traffic data for 1,700 locations in Los Angeles. Burke et al. (2017) found that the monthly fuel price elasticity of traffic flows is -0.1 on Indonesian toll roads. Siddique (2008) estimated that the fuel price elasticity of traffic flows in Perth ranges from -0.09 to zero. Mrkaic and Pezdir (2008) found no significant response of drivers' responses to fuel price changes on Slovenian highways. They explained that this could be because Slovenia has a small geographic size and because a significant share of highway travel is by foreign tourists who are less responsive to changes in the Slovenian gasoline price. The larger dataset here was able to be used to detect significant but small effects in NSW.

Like our study, prior studies thus suggest that drivers are not very sensitive to changes in fuel prices. One possible reason for the very inelastic fuel price elasticity of traffic flows is the ability to switch to greater use of fuel-efficient vehicles such as motorcycles and electric vehicles (EVs) when fuel prices rise. New motorcycle sales have been found to be positively related to gasoline prices (Zhu et al. 2015). Another key reason is that driving is a necessary activity for many people, so it is natural to expect an inelastic response. As discussed, the effect of a higher gasoline price at some times on some roads would also be expected to be an increase in traffic flows due to the alleviation of hypercongested conditions.

The finding of a positive gasoline price elasticity of traffic flows during weekday peak periods is new to the empirical literature, yet in line with what one would expect under hypercongested conditions according to the fundamental diagram of traffic flow. Bento et al. (2013) estimated fuel price elasticities of traffic flow that are negative and larger in magnitude during weekday off-peak periods $(-0.09)$ than weekday peak periods $(-0.05)$ for mainline lanes in Los Angeles. Martin and Thornton (2017) observed a negative effect of road charges on the daily distance travelled during peak periods.

Most international evidence suggests that the fuel-price elasticity of public transport ridership is between 0.05 and 0.40 (Mattson 2008), with elasticities for Australia generally ranging from zero to 0.2 (Kennedy and Wallis 2007). Fullerton and Walke (2013) found that the gasoline price elasticity of public transit ridership is around 0.12 in the US. Currie and Phung (2008) obtained a higher elasticity in Australian cities ( 0.22 for both Melbourne and Adelaide), explaining the finding by pointing to the fact that gasoline prices are substantially higher in Australia than in the US (by 20-30\% as of 2007) due to reasons including Australia's higher fuel excise. The gasoline price elasticity of public transport ridership in this study (0.28) is larger still. This may in part be because residents of Sydney are more likely to substitute to public transport. According to the 2016 Census, the public transport share of work commutes was $20.9 \%$ in Sydney, compared to $13.4 \%$ in Melbourne and $8.3 \%$ in Adelaide (Australian Bureau of Statistics 2017).

\section{Conclusion}

This study has estimated the gasoline price elasticity of traffic flows in NSW, Australia for the period 2010-2017. Using hourly data, the average elasticity was estimated at around -0.04 . Negative and very inelastic estimates were also obtained using daily, weekly, and monthly 
observations. Evidence was found that the effect of gasoline prices on vehicle flows depends on the time of day, with the fuel price elasticity of traffic flows being positive during peak periods on weekdays. This is likely to be because reduced road-use demand ameliorates traffic jams and so means that more vehicles can pass individual count stations per hour at these times. Evidence was also found that average speeds are faster during afternoon peak periods.

This study does not find much in the way of heterogeneity for different types of roads. It was found that higher gasoline prices are associated with a reduction in the quantity of gasoline demanded, with a larger proportional effect size than for vehicle flows. It was also found that higher gasoline prices encourage people to use public transport.

The results of the research hold relevance for predicting vehicle flows and for considering the future calibration of electronic road pricing systems. Even with estimated effect sizes that are quite small in proportional terms, fuel price swings can still lead to quite large changes in vehicle flow numbers. Of most interest is the finding that higher fuel prices can help to increase the flow of vehicles on key roads during key peak hours, consistent with expected density-flow relationships under hypercongested conditions. This suggests that fuel excise can play a role in both reducing overall road dependence and reducing the severity of peak-hour traffic jams.

Another interesting implication of the results is that, by reducing the marginal cost of driving, the rise of electric and autonomous vehicles should be expected to exacerbate traffic jams. This will increase the case for the adoption of a system of electronic road pricing in order to manage valuable road space.

An interesting extension of this work would be to analyze the effect of gasoline prices on traffic densities (cf. traffic flows) if data are available. The expectation would be that higher gasoline prices would reduce congestion levels. Estimates for traffic density could be used to explore if the positive effect of gasoline prices on traffic flows in some peak-hour periods in NSW is indeed due to a reduction in hypercongestion at those times. Further analysis of the effect of gasoline prices on vehicle speeds would also be of interest. 


\section{References}

ANZ-Roy Morgan 2019, ANZ-Roy Morgan Australian CC Monthly Ratings 1973-2019, viewed 20 May 2019, http://www.roymorgan.com/morganpoll/consumerconfidence/consumer-monthly-results.

Austin, D 2008, Effects of gasoline prices on driving behavior and vehicle markets: a CBO study, viewed 20 May 2019, https://www.cbo.gov/sites/default/files/110th-congress-20072008/reports/01-14-gasolineprices.pdf.

Australian Bureau of Meteorology 2019, Climate data online, viewed 20 May 2019, http://www.bom.gov.au/climate/data.

Australian Bureau of Statistics 2017, More than two in three drive to work, Census reveals, viewed 10 May 2020,

https://www.abs.gov.au/ausstats/abs@.nsf/mediareleasesbyreleasedate/7DD5DC715B608612 CA2581BF001F8404.

Australian Bureau of Statistics 2018, 9309.0 - Motor vehicle census, Australia, 31 Jan 2018, viewed 20 May 2019,

https://www.abs.gov.au/ausstats/abs@.nsf/Lookup/9309.0main+features131\%20Jan\%202018

Australian Bureau of Statistics 2019, Consumer price index, viewed 20 May 2019, https://www.abs.gov.au/Price-Indexes-and-Inflation.

Australian Bureau of Transport Statistics 2019, Opal monthly trips, viewed 20 May 2019, https://opendata.transport.nsw.gov.au/dataset/opal-trips-all-modes.

Australian Competition and Consumer Commission 2016, Report on the Australian petroleum market - September quarter 2016, viewed 20 May 2019, https://www.accc.gov.au/system/files/Report\%20on\%20the\%20Australian\%20petroleum\%20 market\%20September\%20quarter\%202016.pdf.

Australian Government Department of the Environment and Energy 2019, Australian petroleum statistics, viewed 20 May 2019, https://www.energy.gov.au/governmentpriorities/energy-data/australian-petroleum-statistics.

Australian Government Department of Jobs and Small Business 2019, Unemployment rate by state and territory, viewed 20 May 2019, http://lmip.gov.au/default.aspx?LMIP/LFR_SAFOUR/LFR_UnemploymentRate.

Australian Institute of Petroleum 2002, To business editors and news directors, viewed 20 May 2019, https://aip.com.au/resources/business-editors-and-news-directors.

Australian Institute of Petroleum 2019, Terminal gate prices, viewed 20 May 2019, https://aip.com.au/historical-ulp-and-diesel-tgp-data.

Bento, AM, Hughes, JE. \& Kaffine, D 2013, 'Carpooling and driver responses to fuel price changes: evidence from traffic flows in Los Angeles', Journal of Urban Economics, vol. 77, pp. 41-56.

Best, R \& Burke, PJ 2019, 'Fuel prices and roads accident outcomes in New Zealand'. New Zealand Economic Papers, vol. 53, no. 2, pp. 109-124.

Billot, R, EI Faozi, NE \& Vuyst, FD 2009, 'Multilevel assessment of the impact of rain on drivers' behavior', Transportation Research Record, vol. 2107, no. 1, pp. 134-142. 
BP Australia 2019, Terminal gate pricing, viewed 20 May 2019, https://www.bp.com/en_au/australia/products-services/pricing/terminal-gate-pricing.html.

Burger, NE \& Kaffine, DT 2009, 'Gas price, traffic and freeway speeds in Los Angeles', Review of Economics and Statistics, vol. 91, no. 3, pp. 652-657.

Burke, PJ 2014, 'Green pricing in the Asia Pacific: an idea whose time has come?', Asia \& the Pacific Policy Studies, vol. 1, no. 3, pp. 561-575.

Burke, PJ \& Nishitateno, S 2013, 'Gasoline prices, gasoline consumption, and new vehicle fuel economy: evidence for a large sample of countries', Energy Economics, vol. 36, pp. $363-370$.

Burke, PJ \& Nishitateno, S 2015, 'Gasoline price and road fatalities: international evidence', Economic Inquiry, vol. 53, no. 3, pp. 1437-1450.

Burke, PJ \& Teame, A 2018, 'Fuel price and road deaths in Australia', Economic Papers, vol. 37, no. 2, pp. 146-161.

Burke, PJ, Batsuuri, T \& Yudhistira, MH 2017, 'Easing the traffic: the effects of Indonesia's fuel subsidy reforms on toll-road travel', Transport Reseach Part A: Policy and Practice, vol. 105, pp. 167-180.

Chi, G, Cosby, AG, Quddus, MA, Gilbert, PA \& Levinson, 2010, 'Gasoline prices and traffic safety in Mississippi', Journal of Safety Research, vol. 41, no. 6, pp. 493-500.

Chi, G, Porter, JR, Cosby, AG \& Levinson, D 2013, 'The impact of gasoline price changes on traffic safety: a time geography explanation', Journal of Transport Geography, vol. 28, pp. 1-11.

Choi, I 2001, 'Unit root tests for panel data', Journal of International Money and Finance, vol. 20, no. 2, pp. 249-272.

Currie, G \& Phung, J 2008, 'Understanding links between transit ridership and gasoline prices: evidence from the United States and Australia', Transportation Research Record, vol. 2061, no. 1, pp. 133-142.

Dahl, CA 1979, 'Consumer adjustment to a gasoline tax', Review of Economics and Statistics, vol. 61, no. 3, pp. 427-432.

Dahl, CA \& Sterner, T 1991, 'Analysing gasoline demand elasticities: a survey', Energy Economics, vol. 13, no. 3, pp. 203-210.

Dickey, DA \& Fuller, WA 1979, 'Distribution of the estimators for autoregressive time series with a unit root', Journal of the American Statistical Association, vol. 74, no. 366, pp. 427431.

Driscoll, JC \& Kraay, AC 1998, 'Consistent covariance matrix estimation with spatially dependent panel data', Review of Economics and Statistics, vol. 80, no. 4, pp. 549-560.

Durbin, J 1954, 'Errors in variables', Revue de L'institut International de Statistique, vol. 22, no. $1 / 3$, pp. 23-32.

Fueltrac 2018, Pump price report, viewed 20 May 2019, http://fueltrac.com.au.

Fullerton, TM Jr \& Walke, AG 2013, 'Public transportation demand in a border metropolitan economy', Applied Economics, vol. 45, no. 27, pp. 3922-3931.

Gillingham, K 2011, How do consumers respond to gasoline price shocks? Heterogeneity in 
vehicle choice and driving behaviour, Working Paper, Yale University, viewed 20 May 2019, http://citeseerx.ist.psu.edu/viewdoc/download?doi=10.1.1.415.2856\&rep=rep1\&type=pdf.

Gillingham, K \& Munk-Nielsen, AM 2019, 'A tale of two tails: commuting and the fuel price response in driving', Journal of Urban Economics, vol. 109, pp. 27-40.

Goodwin, P, Dargay, J \& Hanly, M 2004, 'Elasticities of road traffic and fuel consumption with respect to price and income: A review', Transport Reviews, vol. 24, no. 3, pp. 275-292.

Grabowski, DC \& Morrisey, MA 2004, 'Gasoline prices and motor vehicle fatalities', Journal of Policy Analysis and Management, vol. 23, no. 3, pp. 575-593.

Graham, DJ \& Glaister, S 2002, 'The demand for automobile fuel: a survey of elasticities', Journal of Transport Economics and Policy, vol. 36, no. 1, pp. 1-25.

Hausman, J 1978, 'Specification tests in econometrics', Econometrica, vol. 46, pp. 12511271 .

Hoechle, D 2007, 'Robust standard errors for panel regressions with cross-sectional dependence', Stata Journal, vol. 7, no. 3, pp. 281-312.

Immers LH \& Logghe S 2003, Traffic flow theory, course materials of Traffic Engineering (H111), Catholic University of Leuven, Belgium.

Investing 2019, S\&P/ASX 200 Historical data, viewed 20 May 2019, https://au.investing.com/indices/aus-200-historical-data.

Kennedy, D \& Wallis, I 2007, Impacts of fuel price changes on New Zealand transport, research report, Land Transport New Zealand, Wellington.

Li, S, Linn, J \& Muehlegger, E 2012, Gasoline price and consumer behaviour, Working Paper, National Bureau of Economic Research, viewed 20 May 2019, https://www.nber.org/papers/w17891.pdf.

Litman, T 2019, Understanding transport demands and elasticities: how price and other factors affect travel behaviour, research report, Victoria Transport Policy Institute, Victoria, Canada, viewed 20 May 2019, http://www.vtpi.org/elasticities.pdf.

Martin, LA \& Thornton, S 2017, Can road charges alleviate congestion? Working Paper, University of Melbourne, viewed 20 May 2019, https://papers.ssrn.com/sol3/papers.cfm?abstract_id=3055428.

Mattson, J 2008, 'The effects of gasoline prices on the bus ridership for different types of transit systems', Journal of the Transportation Research Forum, vol. 43, no. 7, pp. 5-21.

Mrkaic, M \& Pezdir, R 2008, 'Estimating price elasticity of demand for highway transport using high frequency data', International Journal of Transport Economics, vol. 35, no. 2, pp. 217-230.

Musso, A, Piccioni, C, Tozzi, M, Godard, G, Lapeyre, A \& Papandreou, K 2013, 'Road transport elasticity: how fuel price changes can affect traffic demand on a toll motorway', Procedia - Social and Behavioral Sciences, vol. 87, pp. 85-102.

NSW Government 2013, Sydney clearways strategy: keeping Sydney moving, viewed 20 May 2019, http://www.transport.nsw.gov.au/sites/default/files/media/documents/2017/sydneyclearways-strategy.pdf. 
NSW Government 2019, The Premier's priorities, viewed 20 May 2019, https://www.nsw.gov.au/improving-nsw/premiers-priorities.

NSW Roads and Maritime Services 2019a, NSW road traffic volume counts, viewed 20 May 2019, https://www.rms.nsw.gov.au/about/corporate-publications/statistics/trafficvolumes/aadt-map/index.html.

NSW Roads and Maritime Services 2019b, Key roads performance report, viewed 5 May 2020, https://www.rms.nsw.gov.au/about/corporate-publications/roads-report.html.

Pesaran MH 2004, General diagnostic tests for cross section dependence in panels, CESifo Working Paper, CESifo Group Munich, viewed 20 May 2019, http://ftp.iza.org/dp1240.pdf.

Phillips, PCB \& Perron, P 1998, 'Testing for a unit root in time series regression', Biometrika, vol. 75, no. 2, pp. 335-346.

Productivity Commission 2006, Road and rail freight infrastructure pricing, Report no. 41, Canberra, Australia, viewed 20 May 2019, https://www.pc.gov.au/inquiries/completed/freight/report/freight.pdf.

Raper, A 2016, 'Opal card: No paper tickets to be used on NSW public transport, concerns for homeless population', $A B C$ News, 1 August, viewed 20 May 2019,

https://www.abc.net.au/news/2016-08-01/opal-card-only-option-on-sydney-public-transportfrom-today/7676698.

Reserve Bank of Australia 2019, Exchange Rates, viewed 23 August 2020, https://www.rba.gov.au/statistics/frequency/exchange-rates.html.

Rohani, MM \& Pahazri, N 2018, 'Survey on how fluctuating petrol prices are affecting Malaysian large city dwellers in changing their trip patterns', Earth and Environmental Science, vol. 140, no. 1, pp. 1-7.

Siddique, S 2008, Travel demand analysis with recent fuel price rise in Perth, research report, Main Roads Western Australia.

Stock, J \& Yogo, M 2005, 'Testing for weak instruments in linear IV regression', in Andrews, DWK and Stock, JH (eds), Identification and Inference for Econometric Models. New York: Cambridge University Press, pp. 80-108.

Torres-Reyan, O 2007, Panel data analysis fixed and random effects using Stata, course materials, Princeton University.

U.S. Energy Information Administration 2019, Petroleum \& other liquids, viewed 23 August 2020, https://www.eia.gov/dnav/pet/hist/RWTCD.htm.

Wilson, FA, Stimpson, JP \& Hilsenrath, PE 2009, 'Gasoline prices and their relationship to rising motorcycle fatalities, 1990-2007', American Journal of Public Health, vol. 99, no. 10, pp. $1753-1758$.

$\mathrm{Wu}, \mathrm{D} 1973$, 'Alternative tests of independence between stochastic regressors and disturbances', Econometrica, vol. 41, pp. 733-775.

Zhu, H, Wilson, FA, Stimpson, JP \& Hilsenrath, PE 2015, 'Rising gasoline prices increase new motorcycle sales and fatalities', Injury Epidemiology, vol. 2, no. 1, pp. 1-8. 


\section{Appendix}

Table A1 New or extended clearway projects

\begin{tabular}{|c|c|c|c|c|c|}
\hline Station code & Road name & Project name & Start date & $\begin{array}{l}\text { Old clearway } \\
\text { hours }\end{array}$ & New clearway hours \\
\hline 28008 & $\begin{array}{l}\text { Centenary } \\
\text { Drive }\end{array}$ & $\begin{array}{l}\text { New clearways on Concord Road, Homebush Bay Drive } \\
\text { and Centenary Drive, Rhodes to Strathfield. }\end{array}$ & 11 April 2016 & $\begin{array}{l}\text { 6am-10am and } \\
3 \mathrm{pm}-7 \mathrm{pm} \text { on } \\
\text { weekdays }\end{array}$ & $\begin{array}{l}\text { 6am-7pm on weekdays; } \\
9 \mathrm{am}-6 \mathrm{pm} \text { on weekends }\end{array}$ \\
\hline $43236 \&$ & Fairford & New and extended clearways on Stacey Street, Fairford & 24 July 2017 & Not a clearway & $6 \mathrm{am}-7 \mathrm{pm}$ on weekdays; \\
\hline 43237 & Road & Road, Davies Road and Alfords Point Road between & & & $9 \mathrm{am}-6 \mathrm{pm}$ on weekends \\
\hline 43246 & $\begin{array}{l}\text { Davies } \\
\text { Road }\end{array}$ & $\begin{array}{l}\text { Hume Highway, Bankstown and Alfords Point Bridge, } \\
\text { Padstow Heights. }\end{array}$ & & & and public holidays \\
\hline 52040 & $\begin{array}{l}\text { Epping } \\
\text { Road }\end{array}$ & $\begin{array}{l}\text { New and extended clearways on Epping Road between } \\
\text { Epping and Lane Cove North. }\end{array}$ & $\begin{array}{l}18 \text { September } \\
2017\end{array}$ & & \\
\hline
\end{tabular}

Notes: Clearway hours are operated in both directions on a specific road. 
Table A2 OLS results using the weighted average of gasoline and diesel prices

\begin{tabular}{|c|c|c|c|c|}
\hline \multirow[t]{2}{*}{ Specification } & Hourly & Daily & Weekly & Monthly \\
\hline & (1) & (2) & (3) & (4) \\
\hline \multirow[t]{2}{*}{ Ln average gasoline and diesel price (real) } & $-0.038 * *$ & $-0.029 *$ & $-0.039 * *$ & -0.029 \\
\hline & $(0.016)$ & $(0.015)$ & $(0.016)$ & $(0.018)$ \\
\hline \multirow{2}{*}{ Ln S\&P/ASX 200 price } & 0.010 & 0.012 & $0.038 * *$ & -0.000 \\
\hline & $(0.019)$ & $(0.017)$ & $(0.018)$ & $(0.024)$ \\
\hline \multirow[t]{2}{*}{ Rainfall (mm) } & $-0.001 * * *$ & $-0.001 * * *$ & $-0.001 * * *$ & $-0.002 * * *$ \\
\hline & $(0.000)$ & $(0.000)$ & $(0.000)$ & $(0.000)$ \\
\hline \multirow[t]{2}{*}{ Maximum temperature $\left({ }^{\circ} \mathrm{C}\right)$} & $0.002 * * *$ & $0.001 * * *$ & 0.001 & $-0.003 * * *$ \\
\hline & $(0.000)$ & $(0.000)$ & $(0.000)$ & $(0.001)$ \\
\hline \multirow[t]{2}{*}{ Public holiday } & $-0.182 * * *$ & $-0.182 * * *$ & $-0.007 *$ & -0.001 \\
\hline & $(0.014)$ & $(0.015)$ & $(0.004)$ & $(0.004)$ \\
\hline \multirow[t]{2}{*}{ School holiday } & $-0.018 * * *$ & $-0.023 * * *$ & $0.004 * * *$ & -0.001 \\
\hline & $(0.002)$ & $(0.003)$ & $(0.001)$ & $(0.001)$ \\
\hline \multirow[t]{2}{*}{ Double demerit period } & $-0.018 * * *$ & $-0.018 * * *$ & $0.048 * * *$ & - \\
\hline & $(0.002)$ & $(0.002)$ & $(0.004)$ & \\
\hline \multirow[t]{2}{*}{ Unemployment rate $(\%)$} & - & - & - & $-0.008 *$ \\
\hline & & & & $(0.005)$ \\
\hline Hour of day dummies & Yes & No & No & No \\
\hline Day of week dummies & Yes & Yes & No & No \\
\hline Within- $R^{2}$ & 0.82 & 0.31 & 0.08 & 0.19 \\
\hline Observations & $11,788,050$ & 485,185 & 58,692 & 5,922 \\
\hline
\end{tabular}

Notes: Coefficients for constants, new clearway dummy, and daylight saving doubled-up hour term are not reported. $* * *, * *$, and $*$ indicate statistical significant at $1 \%, 5 \%$, and $10 \%$ respectively. The within- $R^{2}$ measures the power of the time-varying explanatory variables. The cluster-robust standard errors are shown in parentheses. All columns control for month-of year dummies, station fixed effects, and a time trend. 
Table A3 Coefficients for hour-of-day dummies, day-of-week dummies and month-of-year dummies in column 1 , Table 3

\begin{tabular}{|c|c|}
\hline Dependent variable: $\mathrm{Lr}$ & \\
\hline Ln Real gasoline price & $-0.040 * * *$ \\
\hline & $(0.016)$ \\
\hline Hour 1:00 & $-0.496 * * *$ \\
\hline & $(0.010)$ \\
\hline Hour 2:00 & $-0.690 * * *$ \\
\hline & $(0.018)$ \\
\hline Hour 3:00 & $-0.562 * * *$ \\
\hline & $(0.029)$ \\
\hline Hour 4:00 & 0.030 \\
\hline & $(0.040)$ \\
\hline Hour 5:00 & $0.984 * * *$ \\
\hline & $(0.045)$ \\
\hline Hour 6:00 & $1.713 * * *$ \\
\hline & $(0.044)$ \\
\hline Hour 7:00 & $2.056^{* * *}$ \\
\hline & $(0.042)$ \\
\hline Hour 8:00 & $2.247 * * *$ \\
\hline & $(0.043)$ \\
\hline Hour 9:00 & $2.248 * * *$ \\
\hline & $(0.042)$ \\
\hline Hour 10:00 & $2.247 * * *$ \\
\hline & $(0.041)$ \\
\hline Hour 11:00 & $2.278 * * *$ \\
\hline & $(0.040)$ \\
\hline Hour 12:00 & $2.288 * * *$ \\
\hline & $(0.039)$ \\
\hline Hour 13:00 & $2.287 * * *$ \\
\hline & $(0.037)$ \\
\hline Hour 14:00 & $2.349 * * *$ \\
\hline & $(0.037)$ \\
\hline Hour 15:00 & $2.430 * * *$ \\
\hline & $(0.037)$ \\
\hline Hour 16:00 & $2.452 * * *$ \\
\hline & $(0.037)$ \\
\hline Hour 17:00 & $2.430 * * *$ \\
\hline & $(0.035)$ \\
\hline Hour 18:00 & $2.178 * * *$ \\
\hline & $(0.029)$ \\
\hline Hour 19:00 & $1.788 * * *$ \\
\hline & $(0.024)$ \\
\hline Hour 20:00 & $1.491 * * *$ \\
\hline & $(0.021)$ \\
\hline Hour 21:00 & $1.328 * * *$ \\
\hline
\end{tabular}


$(0.018)$

Hour 22:00

$1.036^{* * * *}$

(0.014)

Hour 23:00

$0.541 * * *$

(0.009)

Monday

$0.118^{* * *}$

(0.008)

Tuesday

$0.148 * * *$

(0.009)

Wednesday

$0.184 * * *$

(0.009)

Thursday

$0.229 * * *$

(0.009)

Friday

$0.286^{* * *}$

(0.008)

Saturday

$0.175 * * *$

(0.005)

February

$0.032 * * *$

(0.004)

March

$0.032 * * *$

(0.004)

April

$0.021 * * *$

(0.005)

May

0.000

$(0.005)$

June

$-0.009$

(0.006)

July

$-0.002$

$(0.007)$

August

0.001

(0.006)

September

$0.013 * *$

(0.005)

October

$0.024 * * *$

(0.004)

November

$0.051 * * *$

(0.004)

December

$0.068 * * *$

(0.004)

Notes: Hour 0:00 is taken as the base hour. Sunday is taken as the base day. January is taken as the base month. ***, **, and * indicate statistical significant at $1 \%, 5 \%$, and $10 \%$ respectively. Cluster-robust standard errors are shown in parentheses. 


\section{Variable definitions and data sources}

Traffic flow: Number of vehicles passing each traffic count station in the hour. All types of motor vehicle are counted. Also measurable at lower levels of frequency (e.g. daily). Source: NSW Roads and Maritime Services (2019a).

Gasoline price (real): Terminal gate price in Australian cents per liter, inclusive of excise and GST. Nominal TGP is taken from the Australian Institute of Petroleum (2019). Measured daily or as a daily average. The consumer price index (CPI) for Sydney was used to adjust the price to a 2017 base. Source of CPI: Australian Bureau of Statistics (2019).

S\&P/ASX 200 price (AXJO): Stock market index of 200 large stocks listed on the Australian Securities Exchange. Measured daily or as a daily average. Source: Investing (2019).

Rainfall: Rainfall in millimeters ( $\mathrm{mm}$ ) in Sydney (Station: Observatory Hill). Measured daily or as a daily average. There are some missing values due to a damaged measuring instrument. Source: Australian Bureau of Meteorology (2019).

Maximum temperature: Daily maximum temperature in Sydney (Station: Observatory Hill). Measured daily or as a daily average. Unit: degrees C. Source: Australian Bureau of Meteorology (2019).

Public holiday dummy: Equals 1 if the day is a public holiday; 0 otherwise.

School holiday dummy: Equals 1 if the day is a public school holiday; 0 otherwise.

New clearway dummy: In hourly estimations, equals 1 if the hour is within new clearway operation time; 0 otherwise. In weekly and monthly estimations, equals 1 if there is a new clearway operated in the week (month); 0 otherwise.

Double demerit period dummy: Equals 1 if the day is within the double demerit period; 0 otherwise.

Daylight saving doubled-up hour: Equals 1 if the hour is repeated due to the end of daylight savings; 0 otherwise. The daylight saving doubled-up hour dummy is switched to an "end of daylight saving" dummy in daily and weekly estimates. It equals 1 if the end of daylight savings fell in that day or week.

Unemployment rate (\%): NSW unemployment rate. Measured monthly. Source: Australian Government Department of Jobs and Small Business (2019).

Time trend: In the hourly and daily traffic flow estimates, a daily time trend is used, which is equal to 1 on 1 January 2010 and increases by 1 in each subsequent day. In the weekly estimates, the time trend is equal to 1 in the first week of 2010 and increases by 1 in each subsequent week. In the monthly estimates, this is equal to 1 in January 2010 and increases by 1 in each subsequent month.

World crude oil price (real): Cushing, OK WTI Spot price FOB (US\$ per barrel). Measured daily or as a daily average. Source: U.S. Energy Information Administration (2019). The unit 
was converted from US\$ per barrel to Australian cents per liter based on the daily AUD/USD exchange rate and a barrel-to-liter conversion. Gaps in the world crude oil price were filled using the same rule as for the gasoline price. Exchange rate source: Reserve Bank of Australia (2019). Then the consumer price index (CPI) for Sydney was used to adjust the price to a 2017 base. Source for CPI: Australian Bureau of Statistics (2019).

Gasoline pump price (real): Pump price for gasoline (unleaded petrol) in Australian cents per liter. Measured monthly. Source: Fueltrac (2018). The consumer price index (CPI) for Sydney is used to adjust the price to a 2017 base. Source for CPI: Australian Bureau of Statistics (2019).

Average speed: Average speed for both morning peak period and afternoon peak period in kilometers per hour. Peak periods are defined by NSW Roads and Maritime Services as being 6-10am and 3-7pm on both weekdays and weekends. Measured monthly. Source: NSW Roads and Maritime Services (2019b).

Consumer confidence index: Australian consumer confidence index. Measured monthly. Source: ANZ-Roy Morgan (2019).

Sales of automotive gasoline: Total automotive gasoline sales in NSW. Unit: megaliters. Measured monthly. Gasoline sales source: Australian Government Department of the Environment and Energy (2019).

Opal card utilization: Opal card utilization figures for all public transport modes (train, bus, light rail, and ferry) in NSW. Measured monthly. Source: Australian Bureau of Transport Statistics (2019). 